ENGINEERING CHANGE NOTICE

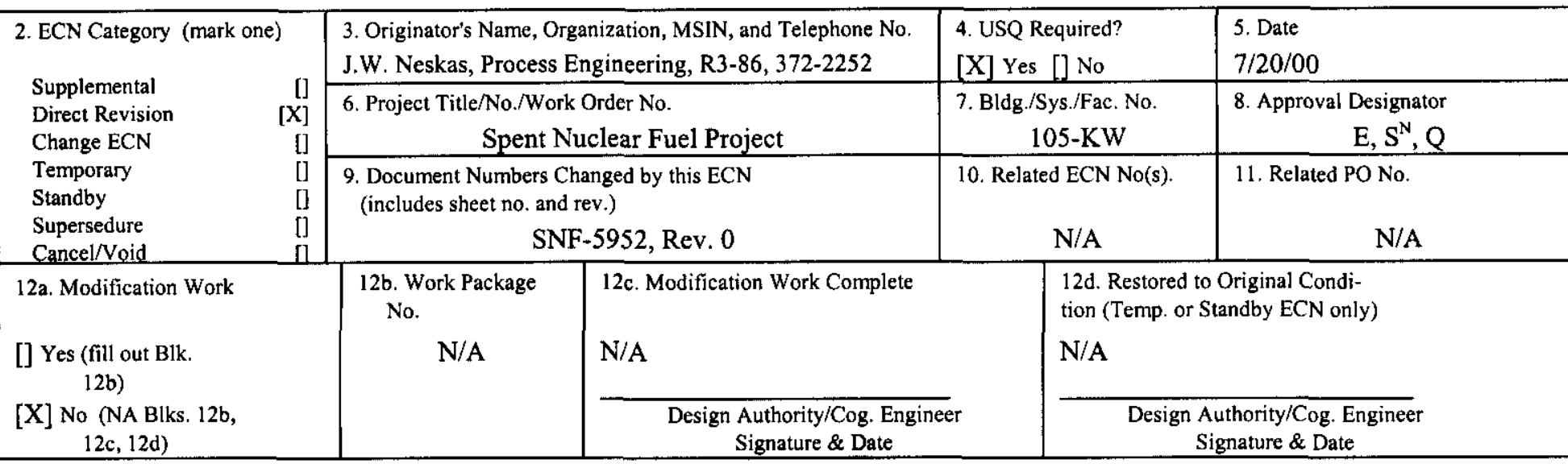

13a. Description of Change

1. Complete document revision.

13b. Design Baseline Document? [] Yes [X] No

2. Added section to provide MCO Fuel Basket loading option for acceptable fuel.

3. Increased scope of test procedure to include Phases 3 and 4.

4. Deleted references to specific Step Numbers and Document Revision Numbers to make procedure more practicable.

5. Clarified test communication between Engineering and Operations.

6. Added IWTS sampling activities.

This document was reviewed in accordance with the document review requirements of AP EN 6-009.

USQ Screening Number: $\quad J, N \cdot 8-3-00$

$$
K-00-1001
$$

$\left.\begin{array}{l}\text { 14a. Justification (mark one) } \\ \text { Criteria Change } \\ \text { Design Improvement }\end{array}\right]$
Environmental
Facility Deactivation
As-Found

15. Distribution (include name, MSIN, and no. of copies) See distribution

14b. Justification Details

Revision updates test procedure to incorporate test scope modifications and comments received on the initial released version. 


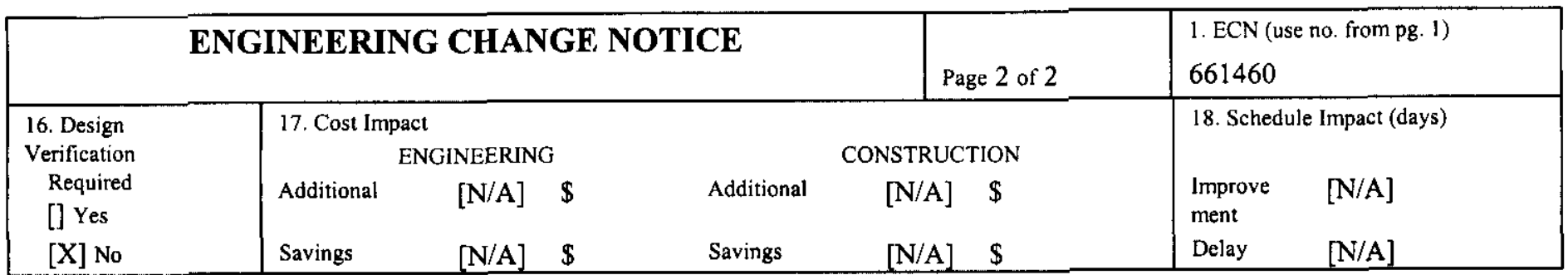

19. Change Impact Review: Indicate the related documents (other than the engineering documents identified on Side 1)

that will be affected by the change described in Block 13. Enter the affected document number in Block 20.

SDD/DD

Functional Design Criteria

Operating Specification

Criticality Specification

Conceptual Design Report

Equipment Spec.

Const. Spec.

Procurement Spec.

Vendor Information

OM Marual

FSAR/SAR

Safety Equjpment List

Radiation Work Pernit

Environmental Impact Statement

Environmental Report
Environmental Permit
[] Seismic/Stress Analysis

[]

[]

[]

[]

[]

[]

[]

[]

[]

[]

[]

[]

[]

[]

[]
Stress/Design Report

Interface Control Drawing

Calibration Procedure

Instaliation Procedure

Maintenance Procedure

Engineering Procedure

Operating Instruction

Operating Procedure

Operational Safery Requirement

IEFD Drawing

Cell Arrangement Drawing

Fssential Material Specification

Fac. Proc. Samp. Schedule

Inspection Plan

Inventory Adjustment Request
[]

[]

[]

[]

[]

[]

[]

[]

[]

[]

[] Process Flow Chart

[] Purchase Requisition

[]

[]
[] Process Control Manual/Plan

\begin{tabular}{ll|} 
Tank Calibration Manual & {[]} \\
Health Physics Procedure & {[]} \\
Spares Multiple Unit Listing & {[]} \\
Test Procedures/Specification & {$[\mathrm{X}]$} \\
Component Index & {[]} \\
ASME Coded Item & {[]} \\
Human Factor Consideration & {[]} \\
Computer Software & {[]} \\
Electric Circuit Schedule & {[]} \\
ICRS Procedure & {[]} \\
Process Control Manual/Plan & {[]} \\
Process Flow Chart & {[]} \\
Purchase Requisition & {[]} \\
Tickler File & {[]} \\
& {[]} \\
& {[]} \\
\hline
\end{tabular}

20. Other Affected Documents: (NOTE: Documents listed below will not be revised by this ECN.) Signatures below indicate that the signing organization has been notified of other affected documents listed below.

Document Number/Revision

Document Number/Revision

Document Number Revision

FTP-OP-PSI-054W, Rev. 0

FTP-OP-PSI-055W, Rev. 0

FTP-OP-PSI-059W, Rev. 0

21. Approvals

Design Authority

Cog. Eng. A. L. Pajunen

Cog. Mgr. J. R. Frederickson

Signature

Cog. Mgr. J. R. Frederickson
QA P. E. Davis
Safety C. T. Miller Hachaffee for

tachereet

Environ. D. J. Watson

Other J. A. Deny $/ 2$ es

V. L. Hoefer

J. J. Klos

J. M. Kurta

J. E. Kurtz $\% \cdot \varepsilon \cdot<2$

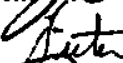

che
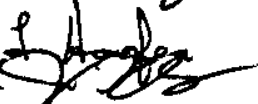

fon 1

J. E. Kurtz $\% \cdot \varepsilon .<$

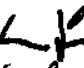

M. J. Langevin

J. D. Mathews

$4 \gamma_{2}=\frac{\pi}{2}=0$

J. W. Neska John W. Nesk at

A. L. Pitner

S. C. Schlegel

J. L. Shelor

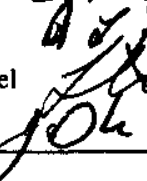

Date

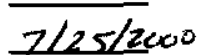

7124100

$8 / 3 / 00$

$8 / 3 / 00$

$8 / 3 / 60$

$2 / 3 / 00$

$\Delta 7 / 19 / 00$

7-25-00

$8 / 3 / 00$

$7 / 26 / 00$

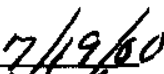

$0 / 3 / 00$

7-19-00

$\frac{7-19-00}{719 / 00}$

7/19\%0

$8 / 3100$
Signature

Date

Design Agent

PE

QA

Safety

Design

Environ.

Other

DEPARTMENT OE ENERGY

Signature or a Control Number that tracks the Approval Signature

ADDITIONAL 
SNF-5952

Revision 1

\section{Phased Startup Initiative Phase 3/4 Test Procedure (OCRWM)}

Prepared for the U.S. Department of Energy Assistant Secretary for Environmental Management

Project Hanford Management Contractor for the

U.S. Department of Energy under Contract DE-AC06-96RL13200

Fluor Hanford

P.O. Box 1000

Richland, Washington 


\title{
Phased Startup Initiative Phase 3/4 Test Procedure (OCRWM)
}

\author{
A. L. Pajunen \\ Fluor Hanford \\ J. W. Neskas \\ WASTREN
}

Date Published

August 2000

Prepared for the U.S. Department of Energy

Assistant Secretary for Environmental Management

Project Hanford Management Contractor for the

U.S. Department of Energy under Contract DE-AC06-96RL13200

\section{Fluor Hanford}

P.O. Box 1000

Richland, Washington
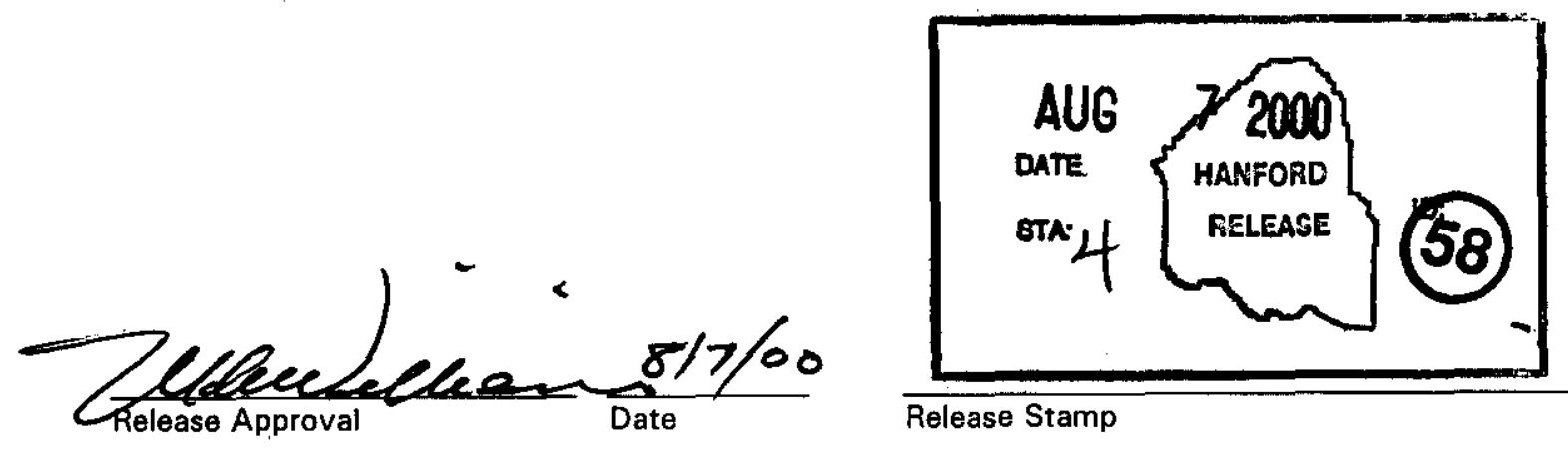
TRADEMARK DISCLAIMER

Reference herein to any specific commercial product, process, or service by trade name, trademark, manufacturer, or otherwise, does not necessarily constitute or imply its endorsement, recommendation, or favoring by the United States Government or any agency thereof or its contractors or subcontractors.

This report has been reproduced from the best available copy. Available in paper copy and microfiche.

Available electronically at $h t t p: / / w w w . d o e . g o v / b r i d g e$. Available for a processing fee to the U.S. Department of Energy and its contractors, in paper, from:

U.S. Department of Energy

Office of Scientific and Technical Information

P.O. Box 62

Oak Ridge, TN 37831-0062

phone: $865-576-8401$

fax: 865-576-5728

email: reports@adonis.osti.gov(423) 576-8401

Available for sale to the public, in paper, from:

U.S. Department of Commerce

National Technical Information Service

5285 Port Royal Road

Springfield, VA 22161

phone: 800-553-6847

fax: 703-605-6900

email: orders@ ntis.fedworld.gov

online ordering: http://wuw.ntis.gov/ordering.htm

Printed in the United States of America

Total Pages: 47 


\section{RECORD OF REVISION}

(2) Title

Phased Startup Initiative Phase 3/4 Test Procedure (OCRWM)

CHANGE CONTROL RECORD

\begin{tabular}{|c|c|c|c|}
\hline \multirow[t]{2}{*}{ (3) Revision } & \multirow[t]{2}{*}{ (4) Description of Change - Replace, Add, and Delete Pages } & \multicolumn{2}{|c|}{ Authorized for Release } \\
\hline & & (5) Cog. Engr. & (6) Cog. Mgr. \\
\hline 0 & (7) Initial release EDT 628539 & $\begin{array}{l}\text { A.L. Pajunen } \\
4 / 11 / 00\end{array}$ & $\begin{array}{l}\text { J.R. Frederickson } \\
4 / 11 / 00\end{array}$ \\
\hline${ }^{1} R S$ & ECN 661460 , August 2000. Complete document revision. & $\begin{array}{l}\text { A.L. Pajunen } \\
\text { Clts }\end{array}$ & J.R. Frederickson 813100 \\
\hline & & & \\
\hline & & & \\
\hline & & & \\
\hline & & & \\
\hline & & & \\
\hline & & & \\
\hline & & & \\
\hline & & & \\
\hline & & & \\
\hline & & & \\
\hline & & & . \\
\hline & & & \\
\hline & & & \\
\hline & & & \\
\hline & & & \\
\hline & & & \\
\hline & & & \\
\hline & & & \\
\hline & & & \\
\hline & & & \\
\hline & & & \\
\hline & & & \\
\hline & & & \\
\hline & & & \\
\hline & & & \\
\hline & & & \\
\hline & & & \\
\hline & & & \\
\hline & & & \\
\hline
\end{tabular}




\section{Phased Startup Initiative Phase 3/4 Test Procedure (OCRWM)}

SNF-5952

Revision No. 1 


\section{SNF-5952, Rev. $\varnothing 1$}

\section{Executive Summary}

The purpose of this test procedure is to provide step-by-step instructions that guide test personnel through the initial testing of the Fuel Retrieval System and Integrated Water Treatment System with N Reactor fuel. This document supports the requirement for preparation of test procedures indicated in the Test Plan Content Guideline of EN-6031-00, "Testing Process."

The scope of this test procedure for Phase 3 is to separately process six fuel canisters, plus contingency canisters. This test procedure will also be used for Phase 4 to separately process 29 canisters, plus contingency canisters. This test procedure provides directions for the testing activities described in HNF-4898, Rev. 1, "Phased Startup Initiative Phases 3 and 4 Test Plan and Test Specifications (OCRWM)."

This test procedure is intended to be primarily used by the Test Engineers, Engineering Test Director (ETD), and Operations Test Director (OTD) to ensure that data is recorded at specific steps during the operational use of Functional Test Procedures and Operating Procedures. The completed data sheets provide documentation of the test progress for each canister to satisfy test control and traceability requirements in HNFPRO-286, "Test Control," and EN-6-031, "Testing Process."

At least three engineers are required for the fuel cleanliness inspection team. One of these engineers is the ETD. The ETD makes testing decisions and provides test direction. The OTD directs operations activities. Communication about test direction for engineering and operations is between the ETD and the OTD. 
SPENT NUCLEAR FUEL PROJECT

Phased Startup Initiative

Phase 3/4 Test Procedure

(OCRWM)
Procedure Number: SNF-5952

Revision: 1

Effective Date: $8 / 7 / 00$

Page 2 of 42

Table of Contents

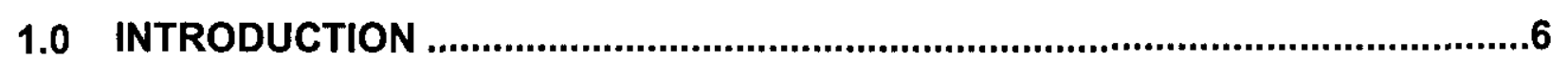

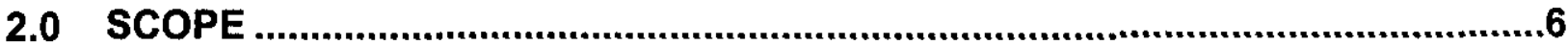

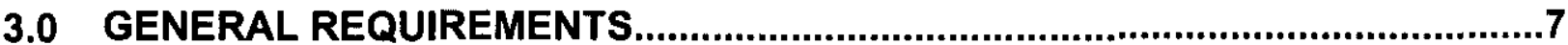

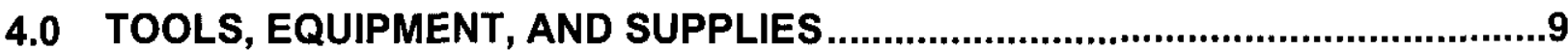

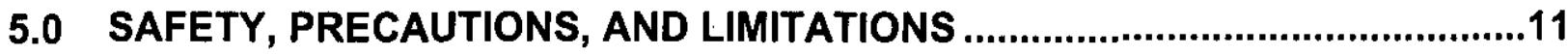

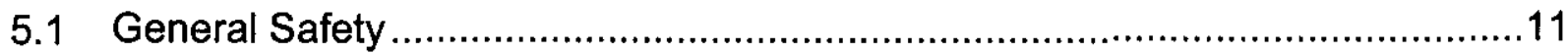

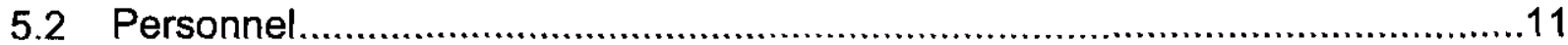

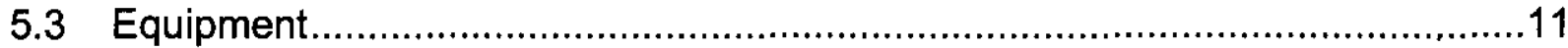

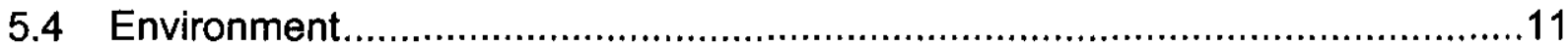

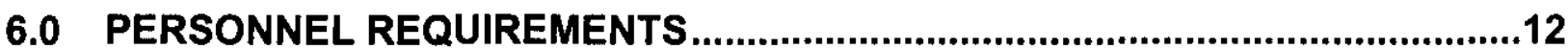

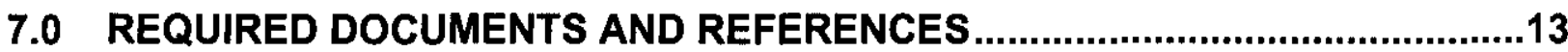

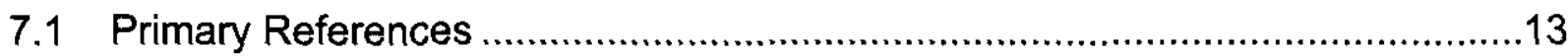

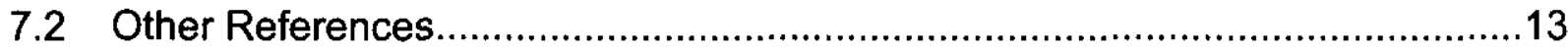

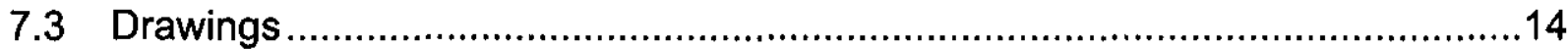

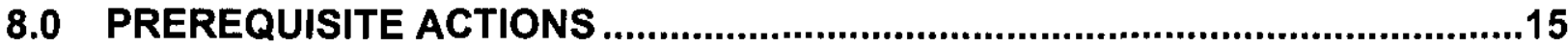

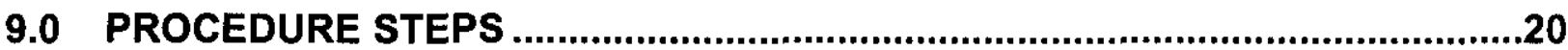

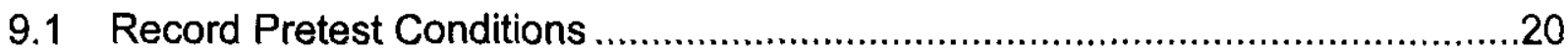

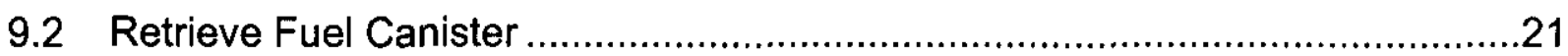

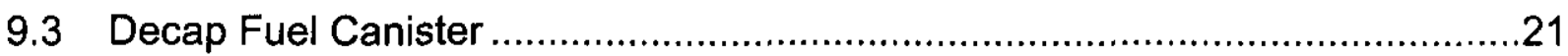

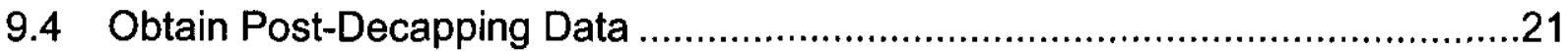

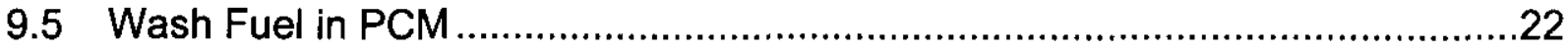

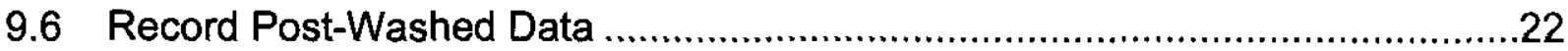

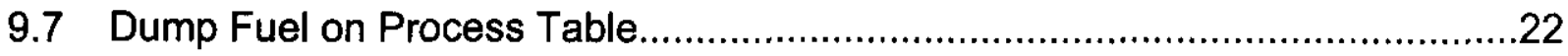

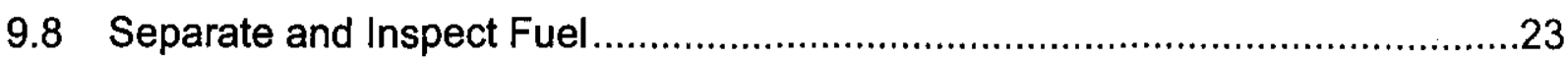

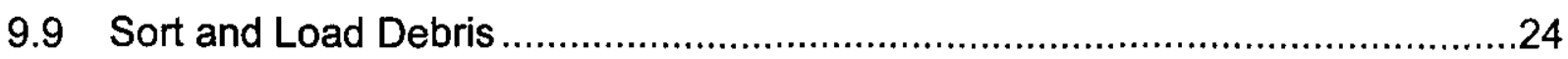

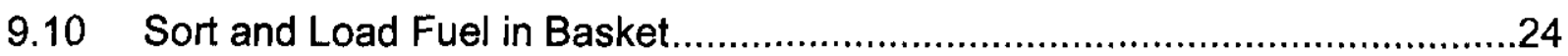

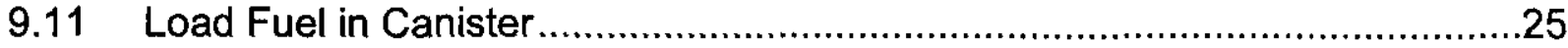

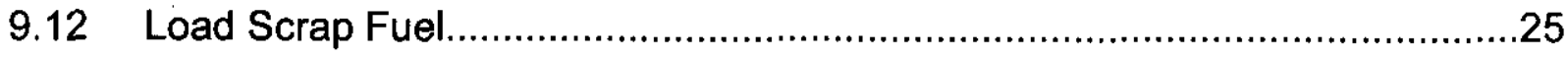


9.13 Sort and Load Coarse Scrap.

9.14 Load Fine Scrap. .26

9.15 Load Scrap from PCM Wash and Strainer Baskets .27

9.16 Process Scrap Canister. .28

10.0 DATA SHEETS.. 29

ATTACHMENT A PHASE 3/4 FRS/IWTS DATA SHEET PAGE 1 OF 7. 30

ATTACHMENT B PHASE 3/4 FRS CLEANING PROCESS DATA SHEET (OCRWM)

PAGE 1 OF 2

ATTACHMENT C TEST EQUIPMENT CALIBRATION LOG....................................39

ATTACHMENT D INSTALLED EQUIPMENT CALIBRATION LOG...........................40

ATTACHMENT E END-OF SHIFT TEST STATUS REPORT, PSI PHASE 3/4 ..........41

ATTACHMENT F PRE-JOB SAFETY BRIEFING SIGNATURE SHEET 


\section{List of Acronyms}
AJHA Automated Job Hazard Analysis
CAM Continuous Air Monitor
CCTV Closed Circuit Television
DI Deionized
DP Data Point
ECN Engineering Change Notice
EOC Equipment Operations Center
ETD Engineering Test Director
FRS Fuel Retrieval System
FTP Functional Test Procedure
HEPA High-Efficiency Particulate Air
HPP High-Pressure Pump
HPU Hydraulic Power Unit
KOP Knockout Pot
IWTS Integrated Water Treatment System
IXM Ion Exchange Module
M\&TE Measuring and Test Equipment
MCO Multi-Canister Overpack
PCM Primary Cleaning Machine
PSI Phased Startup Initiative
OCRWM Office of Civilian Radioactive Waste Management
OTD Operations Test Director
QA Quality Assurance
QAE/I Quality Assurance Engineer/Inspector
QC Quality Control
RBA Radiological Buffer Area
RMA Radioactive Material Area
SNF Spent Nuclear Fuel 


\section{SPENT NUCLEAR FUEL PROJECT}

Phased Startup Initiative

Phase 3/4 Test Procedure

(OCRWM)

TE

TSB Test Engineer

Telescoping Stiffback
Procedure Number: SNF-5952

Revision: 1

Effective Date: $8 / 7 / 00$

Page 5 of 42 


\subsection{INTRODUCTION}

The purpose of this test procedure is to safely operate the Fuel Retrieval System (FRS) and Integrated Water Treatment System (IWTS) with specific fuel canisters, and show that canisters containing fuel can be retrieved from the canister queue, decapped in the Canister Decapper, and loaded into the Primary Clean Machine (PCM) for fuel cleaning; and that fuel can be sorted on the Process Table, then loaded back into fuel canisters and relocated in basin storage. An option is included to load selected elements into multi-canister overpack (MCO) Fuel Baskets.

Additional Data are collected during this test, beyond that collected during production operations. These data support qualifying the cleaning performance of the PCM, assessing the quantity of scrap generated during the cleaning, and evaluating the impact of fuel retrieval operations on the Basin water quality. The additional data collected primarily consist of weighing fuel and scrap at selected points in the operation, as well as photographing fuel and scrap as it is processed. The time to perform operations is also monitored for comparison with design predictions. Water quality data are collected to establish a baseline to predict the effectiveness of equipment design for control of contamination and visibility during production operation.

\subsection{SCOPE}

The scope of this test procedure is to validate the operation of FRS and IWTS components as a complete system. The Phase 3 test method is to individually process six specific fuel canisters through the FRS. The Phase 4 test method is to individually process 29 specific fuel canisters through the FRS. One fuel canister shall be completely processed in accordance with this test procedure before another canister is started in the process. The Phase 3 test sequence is to process six canisters. Contingency canisters have been identified, and will be processed if cleaning parameter variation is required. The Phase 4 test sequence is to process 29 canisters. Contingency canisters have been identified and will be processed to complete process validation, if necessary. The fuel canisters to be processed shall be listed in the Fuel Campaign Letter and are identified in HNF-4898, "Phased Startup Initiative Phases 3 and 4 Test Plan and Test Specifications (OCRWM)". (The acronym OCRWM is required to appear in titles of documents that collect data needed by the Office of Civilian Radioactive Waste Management.) 


\subsection{GENERAL REQUIREMENTS}

3.1 This procedure is under the direct control of the Operations Test Director (OTD).

3.2 Direction for this procedure for the Test Engineers (TEs) will be provided by the Engineering Test Director (ETD), or designee.

3.3 The ETD will coordinate the test, review test results, and determine corrective actions. Test Engineers (TEs) will support the ETD in the recording and evaluation of data.

3.4 A pretest briefing for all personnel involved in the performance of the test shall be conducted at the beginning of each shift. When new test team members assume test duties, they can be briefed individually. The time and date of each briefing shall be documented in the test log.

3.5 Operations procedures, as applicable, including all safety procedures, shall apply to this test activity. The Pre-Job Safety Briefing Signature Sheet shall attest to having read the required safety procedures, such as the current Automated Job Hazard Analysis (AJHA), criticality postings, and the as low as reasonably achievable (ALARA) Management Worksheet.

3.6 Fuel Inspection and Process Engineers involved with testing activities shall have a Phased Startup Initiative (PSI) Qualification (Qual Card) and completed Office of Civilian Radioactive Waste Management (OCRWM) training.

3.7 Stuck fuel will not be processed during conduct of this Procedure. If a canister is found to contain stuck fuel, it shall be noted on the data sheet and returned to basin storage.

3.8 Fuel shall be inspected by the Fuel Inspection Team per HNF-5271, "Planning Document for Spent Nuclear Fuel Cleanliness Inspection Process (OCRWM)".

3.9 Selected fuel elements may be loaded into MCO Fuel Baskets, or back into canisters, at the direction of the Engineering and Operations Test Directors.

3.10 Scrap fuel shall be loaded back into canisters. No scrap fuel shall be loaded into MCO Scrap Baskets. The MCO Baskets shall be in place in the Process Table to prevent dropped fuel from falling into the MCO Basket Sockets.

3.11 The Fuel Status Inventory that remains on the Process Table at the end of each shift shall be provided to K Area Security. 
3.12 Elapsed time shall be measured for certain process operations by recording the "Start" and "End" clock time. Any process down time that interrupts the normal work procedure of a process being evaluated shall be recorded in the Comments section on Phase 3/4 FRS/IWTS Data Sheet. Examples of process down time are recording Photographs and Weights, Continuous Air Monitor (CAM) alarms, equipment malfunction, or suspended operations.

3.13 For each canister, the Test Process shall be documented and tracked by the Phase 3/4 FRS/IWTS Data Sheet (Attachment A), and the End of Shift Test Status Report (Attachment E).

3.14 Data Sheets will be specific to a particular canister and assimilated into a canister specific Data package.

3.15 Checklists, Data Sheets, Photographs, and other test data collected as the tests are performed will be stamped in red ink as the "Test Control Copy." The test control copy of data will be maintained by the ETD/TE in the Test Data binder, located at the fuel inspection team desk in the basin Equipment Operations Center (EOC). At the end of each work day, the ETD/TE will make a copy of new data accumulated over the work day, stamp these data in red ink as "Duplicate of Original, Do Not Revise," and insert the data in the Back-Up Test Data binder located in the ETD's office in MO-285.

3.16 Water samples shall be analyzed to calculate waste loading on ion exchange modules (IXMs) IXM-1, IXM-2, and IXM-3. Composite water samples will be taken from the IXM common inlet and the IXM outlets while the IWTS is in service. The sample number, sample bottle change-out time, and composite sampler setting will be recorded in the 105-KW Process Monitoring Sample Label Book. This sample data and the sample analysis results shall be recorded in the Test Data binder.

3.17 The start time and end time for the IWTS in service and the garnet filter backwash and top sparge shall be recorded in the comments section of the Phase 3/4 FRS/IWTS Data Sheet.

3.18 Upon completion of Phase 4 testing, the PCM wash basket shall be removed from the PCM to inspect the PCM internals and obtain a video recording and hard copy printout of close-ups of the bearing surfaces and bearing wear indicator marks to support the evaluation started in SNF-A.7-PAT-010A, Rev. 1, Step 9.17.2. 


\subsection{TOOLS, EQUIPMENT, AND SUPPLIES}

4.1 Weigh Station (shortened fuel canister hook with scale)

4.2 One VCR clock in the EOC shall be selected by the ETD and used to measure elapsed time to the nearest minute for certain operational activities and to record down time.

4.3 Special gage to measure scrap depth in canister

4.4 Sludge Collection Tray

4.5 Grid Plate with 1 inch markings

4.6 One inch sieve for separating fine scrap

4.7 Sludge Pickup Adapter and Installation Fixture

4.8 Turbidimeter near Process Table

4.9 PCM Discharge Radiation Monitor

4.10 Continuous Air Monitor (CAM) with recording of Krypton 85 concentration in local operator area near Decapping Station

4.11 Items Listed in Functional Test Procedures (FTPs):

4.10.1 Fuel basket

4.10.2 Jib crane with empty basket grapple attached in corridor \#7

4.10.3 1 ton monorail hoist with empty basket grapple attached at monorail 27 extension

4.10.4 Pallet jack in corridor \#10

4.10.5 Basin transfer cart in corridor \#7

4.10.6 Long pole hook

4.10.7 Long pole tool

4.10.8 Modified peters tool

4.10.9 Rope hook

4.10.10 Empty Type MK I and MK II fuel canisters

4.10.11 Telescoping stiffback

4.10.12 Decapping tools

4.10.13 Debris bin

4.10.14 Canister lid debris bin

4.10.15 Closed Circuit Television (CCTV) 
SPENT NUCLEAR FUEL PROJECT

Phased Startup Initiative

Phase 3/4 Test Procedure

(OCRWM)
Procedure Number: SNF-5952

Revision: 1

Effective Date: 8/7/00

Page 10 of 42

4.10.16 Gas tube crimper and cutting tool

4.10.17 Deionized (DI) water hose

4.10.18 Air compressor (minimum $150 \mathrm{scfm}, 90$ psig) for IWTS air sparge process

4.10.19 Sparger (also called "spray wand") 


\subsection{SAFETY, PRECAUTIONS, AND LIMITATIONS}

\subsection{General Safety}

5.1.1 If an abnormal or unexpected condition arises during the performance of this test, the associated systems will be placed in a safe and stable condition. The OTD will evaluate and implement required actions.

5.1.2 Any equipment or facility damage resulting from an abnormal or unexpected condition requires that the test be terminated after placing the associated systems in a safe and stable condition. The OTD, along with the Facility Manager (or designee), will determine restart conditions.

\subsection{Personnel}

5.2.1 Personnel on the test team shall conduct themselves and the test in accordance with ALARA practices. If testing is delayed or direct observation is not required unessential personnel will leave the radiological buffer area/radioactive material area (RBA/RMA) or report to the standby area as indicated on the survey map.

5.2.2 Personnel on the test team shall immediately bring any personnel safety concerns to the attention of the OTD, the Facility Manager, or the Shift Supervisor for immediate resolution.

\subsection{Equipment}

5.3.1 If used in automatic sequence mode, the IWTS control system should not be started more than twice within any five minute period.

\subsection{Environment}

5.4.1 The high-efficiency particulate air (HEPA) filters associated with the filter vessel vent are an environmental effluent control device. The HEPA filters must be installed and operational before the filter vessels are allowed to vent or air sparging is allowed to take place with radioactive air emissions. 


\subsection{PERSONNEL REQUIREMENTS}

6.1 Personnel of the following types will be needed to support performance of this test:

Classification

Quality Assurance Engineer/Inspector (QAE/l)

Operator

Rad. Con.

Fuel Cleanliness Inspection Team (minimum of three during Test performance)

TEs

ETD (the ETD is one member of the Fuel Cleanliness Inspection Team) OTD

\section{${ }^{\star}$ Quantity}

1

4

2

5

2

1

1

${ }^{*}$ Additional numbers of each personnel type may be required at different times during Test performance. 


\subsection{REQUIRED DOCUMENTS AND REFERENCES}

\subsection{Primary References}

Procedure Number

FTP-OP-PSI-054W

FTP-OP-PSI-055W

FTP-OP-PSI-059W

\subsection{Other References}

Procedure Number

FTP-OP-70-001W

FTP-OP-70-002W

FTP-OP-70-003W

FTP-OP-70-004W

FTP-OP-70-005W

FTP-OP-70-006W

FTP-OP-70-007W

FTP-OP-70-008W

FTP-OP-70-009W

FTP-OP-70-0010W

FTP-OP-70-0011W

FTP-OP-70-0012W

FTP-OP-70-0013W

FTP-OP-70-0015W

FTP-OP-70-050W

FTP-OP-70-051W

FTP-OP-70-053W

FTP-OP-70-056W

FTP-OP-70-057W

FTP-OP-70-058W

FTP-OP-70-060W

FTP-OP-70-061W
Procedure Title

Process Table Fuel Operations (OCRWM)

Fuel Decap/Wash Operations

Loading and Capping of Fuel/Scrap Canisters

\section{Procedure Title}

Perform Normal IWTS Electrical Lineup at 105-KW

Perform Initial IWTS Manual Valve Lineup at 105-KW

Fill And Vent IWTS Filter System at 105-KW

Fill And Vent IWTS Distribution Header at 105-KW

Operate IWTS at 105-KW

Backwash Garnet Filter at 105-KW

Top Sparge Garnet Filter

Air Sparge Garnet Filter

Install IWTS IXMs at 105-KW

Isolate Drain and Remove IWTS IXM at 105-KW

Switch IWTS IXM Flow at 105-KW

Perform FRS/IWTS Patrol

Change Out Knockout Pots

Collect IWTS IXM Water Samples at 105-KW

Transfer Fuel Baskets from Corridor 10 to Basin

Normal Startup/Shutdown of Manipulator System

Assume EOC Operations

Flexible Transfer Crane

Exercise Manipulator Joints

Sample HPU Hydraulic Fluid

Exercise Manipulator Arms

Off Gas System Operation 
SPENT NUCLEAR FUEL PROJECT

Phased Startup Initiative

Phase 3/4 Test Procedure

(OCRWM)

OP-07-113W

OP-14-002

OP-16-002W

OP-43-015

OP-43-035W

RP-05-035

\subsection{Drawings}

$\mathrm{H}-1-83302$

$\mathrm{H}-1-83944$
Procedure Number: SNF-5952

Revision: 1

Effective Date: 8/7/00

Page 14 of 42

Position and Secure Irradiated Fuel at $105 \mathrm{KW}$

Perform Pre-Use Test on Hoists

Operate Demineralized Water Hose Bib System at $105 \mathrm{KW}$

Collect Special Water Samples from Routine Sample Locations

Collect Center of Basin Air Permit Water Sample

Operation of the Triton KR-85 Monitor

KW Fuel Storage Basin IWTS P\&ID

KW Fuel Storage Basin FRS P\&ID 
SPENT NUCLEAR FUEL PROJECT

Procedure Number: SNF-5952

Phased Startup Initiative

Revision: 1

Phase 3/4 Test Procedure

Effective Date: $8 / 7 / 00$

(OCRWM)

Page 15 of 42

\subsection{PREREQUISITE ACTIONS}

Prerequisite actions may be performed in any order.

Items must be satisfied prior to beginning Daily Pre-Startup Checklist.

Test Engineers Pre-Startup Checklist (perform once prior to starting test):

\begin{tabular}{|c|c|c|c|}
\hline & Action & Initial/Date & Comments \\
\hline \multirow[t]{2}{*}{1} & $\begin{array}{l}\text { Open items have been evaluated and verified to not affect the } \\
\text { performance of this test }\end{array}$ & & \\
\hline & $\begin{array}{l}\text { NOTE: Type of open items to evaluate include Quality } \\
\text { Assurance (QA) nonconformance reports, construction punch } \\
\text { list, outstanding engineering or design change notices, startup } \\
\text { field requests, or test deficiency reports. }\end{array}$ & & \\
\hline 2 & $\begin{array}{l}\text { A walkdown inspection of the equipment associated with this } \\
\text { test procedure has been performed. All components are } \\
\text { labeled in accordance with the approved drawings listed in } \\
\text { Section } 7.3 \text {. }\end{array}$ & & \\
\hline 3 & $\begin{array}{l}\text { Perform an initial briefing for personnel involved in the } \\
\text { performance of this test. }\end{array}$ & & \\
\hline 4 & $\begin{array}{l}\text { Perform the ALARA Pre-Implementation meeting for personnel } \\
\text { involved in the performance of this test. }\end{array}$ & & \\
\hline 5 & $\begin{array}{l}\text { The ETD has determined appropriate interface and support } \\
\text { personnel from other organizations have been notified and are } \\
\text { available. }\end{array}$ & & \\
\hline 6 & OTD notified of scheduled Test and Time. & & \\
\hline 7 & $\begin{array}{l}\text { Verify that the Fuel Inspection Team members are notified prior } \\
\text { to commencement of testing. (preferably } 24 \text { hours) }\end{array}$ & & \\
\hline 8 & $\begin{array}{l}\text { Verify that the Spent Nuclear Fuel (SNF) QA is notified prior to } \\
\text { commencement of testing. (preferably } 24 \text { hours) }\end{array}$ & & \\
\hline 9 & $\begin{array}{l}\text { Verify that the DOE facility representative is notified prior to } \\
\text { commencement of testing. (preferably } 24 \text { hours) }\end{array}$ & & \\
\hline
\end{tabular}




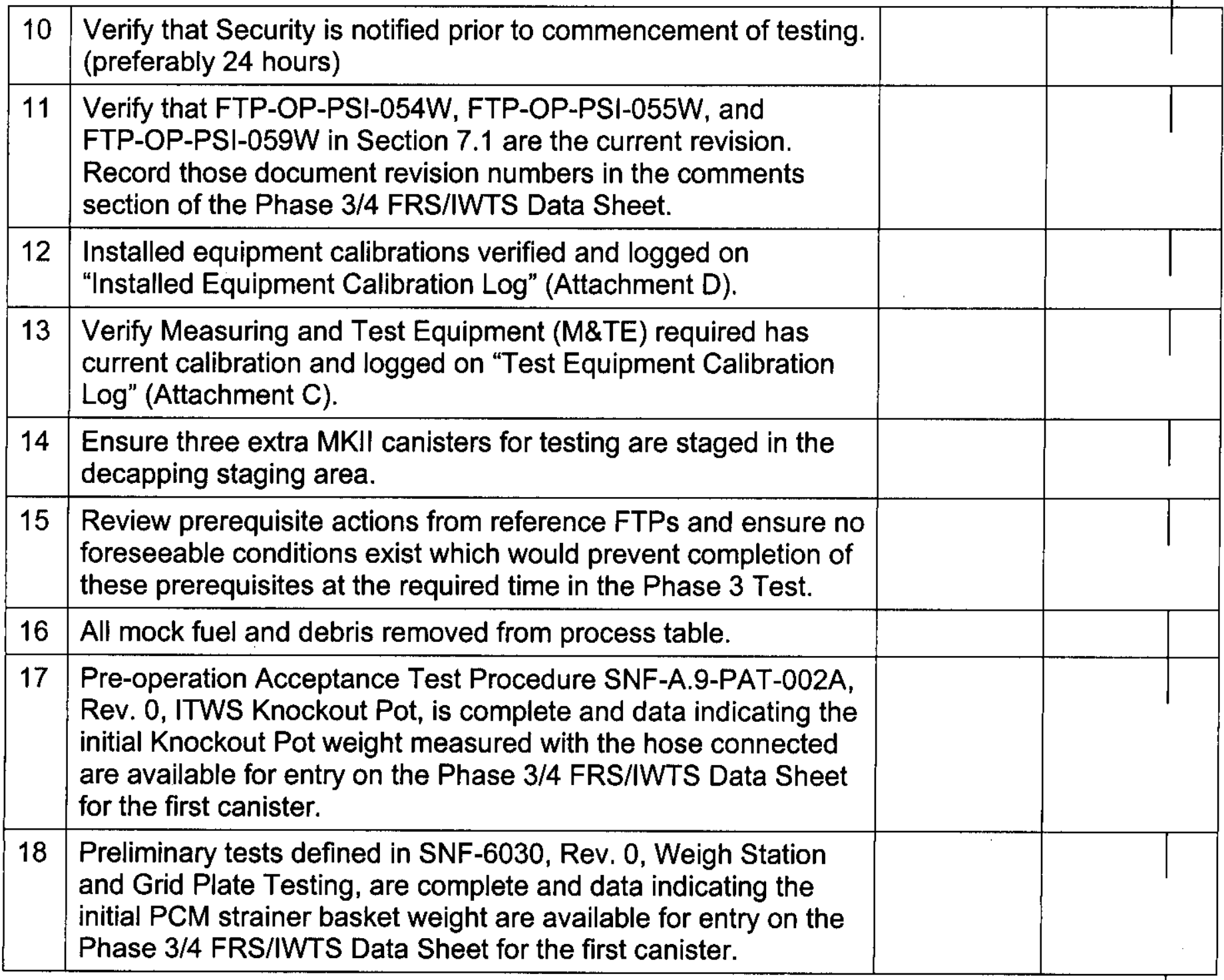

I have reviewed the above prerequisites and initial conditions. The prerequisites and initial conditions that are required to commence Section 9.0 are complete. I recommend that this PSI Test be released for performance. 
I have reviewed the above prerequisites and initial conditions. The prerequisites and initial conditions that are required to commence Section 9.0 are complete. I recommend that this PSI Test be released for performance. 
DAILY PRE-STARTUP CHECKLIST (perform prior to starting each day of test activity):

\begin{tabular}{|c|c|c|c|}
\hline & Action & Initial/Date & Comments \\
\hline 1 & $\begin{array}{l}\text { Required Witnesses Available: } \\
\text { QAE/I } \\
\text { Fuel Inspection Team }\end{array}$ & & \\
\hline 2 & $\begin{array}{l}\text { Verify test personnel and witnesses have read } \\
\text { and signed AJHA. }\end{array}$ & & \\
\hline 3 & $\begin{array}{l}\text { Personnel who will be involved with this procedure } \\
\text { have provided the required signature verification } \\
\text { information on the "Pre-Job Safety Briefing } \\
\text { Signature Sheet" (Attachment F). }\end{array}$ & & \\
\hline 4 & $\begin{array}{l}\text { IWTS operating with IXM inlet radiation monitor } \\
\text { and strip chart recorder activated. }\end{array}$ & & \\
\hline 5 & FRS operational and ready to process fuel. & & \\
\hline 6 & $\begin{array}{l}\text { Manipulator system started-up and ready to } \\
\text { process fuel. }\end{array}$ & & \\
\hline 7 & Campaign Letter. & & \\
\hline 8 & Scrap Basket cover installed. & & \\
\hline 9 & $\begin{array}{l}\text { Record center of basin grab sample number and } \\
\text { obtain analysis results. }\end{array}$ & & \\
\hline & & & \\
\hline & y PreStartup Checklist Verified Complete_ & & Date \\
\hline
\end{tabular}




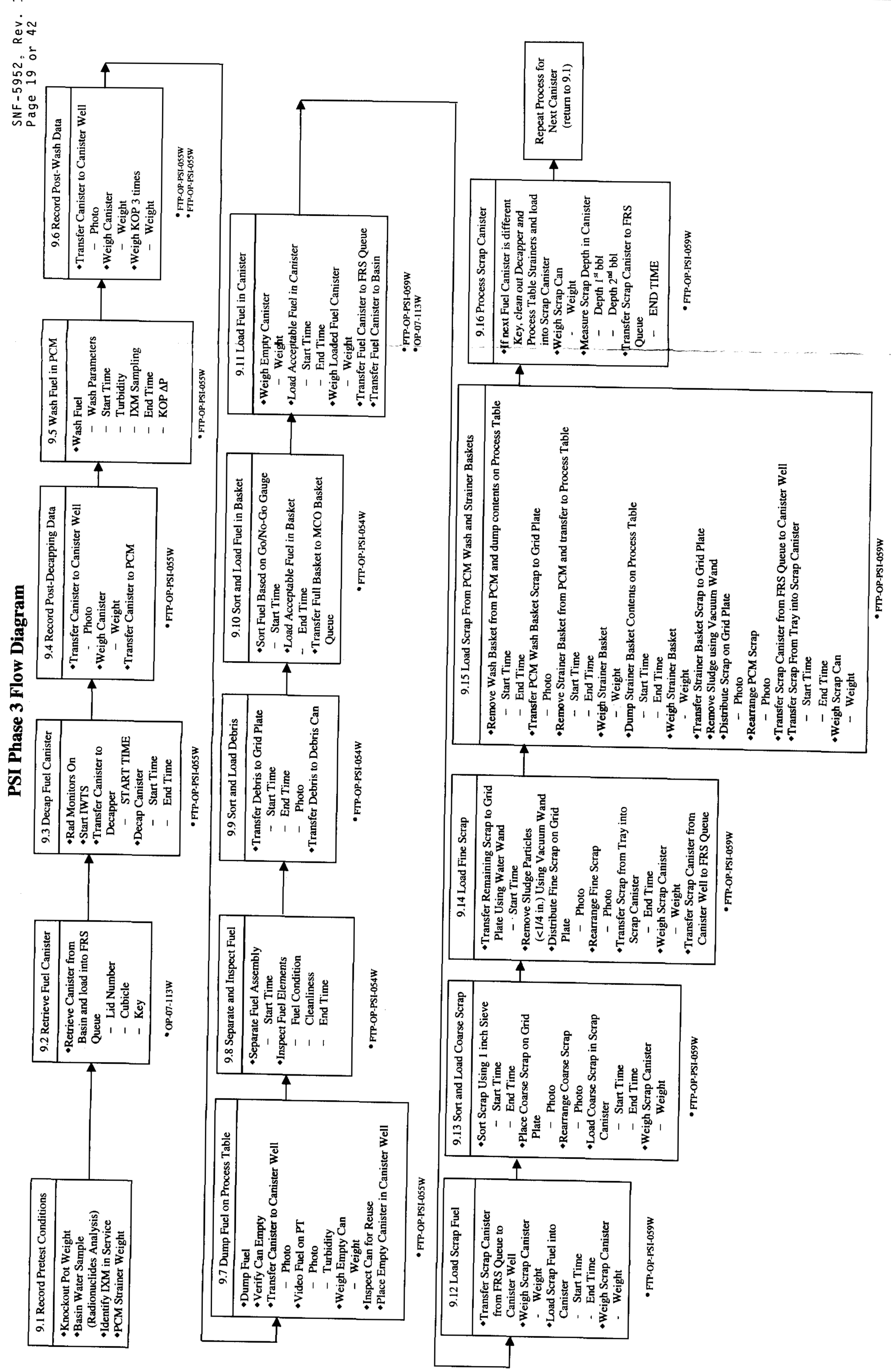




\subsection{PROCEDURE STEPS}

\subsection{Record Pretest Conditions}

1. Signature verifications on Section 8.0 Checklists signify that the Prerequisite Actions are complete.

2. Signature verification on Phase $3 / 4$ FRS/IWTS Data Sheet signifies that the current procedure revision of FTP-OP-PSI-054W, FTP-OPPSI-055W, and FTP-OP-PSI-059W is being used. This verification also confirms that any changes to the primary references in Section 7.1 have been evaluated for any effect to this Test Procedure. Any required changes to this Test Procedure shall be incorporated by an Engineering Change Notice (ECN) and approved by Engineering, Environmental, Operations, Nuclear Safety, and QA.

DP-1 3. Record Knockout Pot (KOP) Load Cell Tare Weight indicated on the Phase 3/4 FRS/IWTS Data Sheet for the previous canister processed (note data source in data sheet comments).

DP-2 4. Record KOP weight data from the end weights indicated on the Phase 3/4 FRS/IWTS Data Sheet for the previous canister processed (note data source in data sheet comments).

NOTE: If this is the first canister processed, Knockout Pot weight is obtained from Pre-operational Acceptance Test SNF-A.9-PAT002A results.

DP-3 5. Record sample number for the center of basin grab sample, obtained per Process Standard 408, on the Phase 3/4 FRS/IWTS Data Sheet.

DP-4 6. Identify IXMs in service and record on Phase 3/4 FRS/IWTS Data Sheet.

DP-5 7. Record PCM Strainer Scale Tare Weight indicated on the Phase 3/4 FRS/IWTS Data Sheet for the previous canister processed (note data source in data sheet comments).

DP-6 8. Record PCM Strainer Weight data from the end weight indicated on the Phase 3/4 FRS/IWTS Data Sheet for the previous canister processed (note data source in data sheet comments).

NOTE: If this is the first canister processed, the empty PCM strainer weight is obtained from preliminary tests defined in SNF6030 . 


\subsection{Retrieve Fuel Canister}

1. Request Operations to position fuel canister listed in the Fuel Campaign letter in fuel queue. (OP-07-113W)

DP-7 2. Record the following data on Phase $3 / 4$ FRS/IWTS Data Sheet:

Date

Phase

Canister Lid \#

Cubicle Location

Key \#

\subsection{Decap Fuel Canister}

1. Request OTD to verify with RadCon Supervisor that Krypton 85 Monitor is in operation per RP-05-035.

2. Request OTD to activate Decapper/PCM Discharge Radiation Monitor.

NOTE: Signature verfication on Phase $3 / 4$ FRS/IWTS Data Sheet signifies that the Decapper/PCM Discharge Radiation Monitor is activated.

3. Request OTD to start with Decapping process (FTP-OP-PSI-055W).

DP-8 4. Record START TIME on Phase 3/4 FRS/IWTS Data Sheet.

DP-9 5. Record Decapping Start Time on Phase 3/4 FRS/IWTS Data Sheet.

DP-10 6. Record Decapping End Time on Phase 3 /4 FRS/IWTS Data Sheet.

\subsection{Obtain Post-Decapping Data}

1. Request OTD to remove decapped canister from Decapping Station (FTP-OP-PSI-055W).

DP-11 2. Record Top View Photograph of fuel in decapped canister. NOTE: Signature verification on Phase 3/4 FRS/IWTS Data Sheet signifies that Top Photo has been recorded.

3. Notify OTD that photograph has been recorded.

DP-12 4. Record Scale Tare Weight on Phase 3/4 FRS/IWTS Data Sheet.

DP-13 5. Record Canister Weight on Phase 3/4 FRS/IWTS Data Sheet. 


\subsection{Wash Fuel in PCM}

1. Notify the OTD of the high-pressure pump (HPP) flow to be used in the next PCM cleaning cycle.

2. Notify the OTD whether operating time or other PCM cleaning cycle parameter changes are needed for the next PCM cleaning cycle.

3. Request OTD to start PCM Wash Cycle (FTP-OP-PSI-055W).

DP-14 4. Record Wash Start Time on Phase 3/4 FRS/IWTS Data Sheet.

5. Request OTD to obtain Reading for Turbidity of Water midway through cleaning cycle.

DP-15 6. Record Turbidity data on Phase 3/4 FRS/IWTS Data sheet.

DP-16 7. Record Wash End Time on Phase 3/4 FRS/IWTS Data Sheet.

DP-17 8. Record Knockout Pot Pressure Drop on Phase 3/4 FRS/IWTS Data Sheet.

\subsection{Record Post-Washed Data}

1. Record canister information on Phase 3/4 Cleaning Process Data Sheet (OCRWM)

2. Request OTD to obtain PCM operating parameters and record on Phase 3/4 Cleaning Process Data Sheet (OCRWM).

DP-18 3. Record Top View Photograph of washed fuel in canister.

NOTE: Signature verification on Phase 3/4 FRS/IWTS Data Sheet signifies that Top Photo has been recorded.

4. Notify OTD that photograph has been recorded.

DP-19 5. Record Scale Tare Weight on Phase 3/4 FRS/IWTS Data Sheet.

DP-20 6. Record Canister Weight on Phase 3/4 FRS/IWTS Data Sheet.

7. Request OTD to weigh Knockout Pot three times (FTP-OP-PSI-055W).

DP-21 8. Record Load Cell Tare Weight on Phase 3/4 FRS/IWTS Data Sheet.

DP-22 9. Record KOP Weight on Phase 3/4 FRS/IWTS Data Sheet.

\subsection{Dump Fuel on Process Table}

1. Request OTD to Dump Fuel onto Process Table (FTP-OP-PSI-055W). 
DP-23 2. Record Top View Photograph of empty canister.

NOTE: Signature verification on Phase 3/4 FRS/IWTS Data Sheet signifies that Empty Canister Top Photo has been recorded.

DP-24

3. Record Photograph of dumped fuel.

Note: Signature verification on Phase 3/4 FRS/IWTS Data Sheet signifies Dumped Fuel Photo has been recorded.

4. Notify OTD that fuel and canister photographs have been recorded.

5. Request OTD to obtain Turbidity Reading.

DP-25 6. Record Turbidity on Phase 3/4 FRS/IWTS Data Sheet.

NOTE: If canister contains stuck fuel, the dumped fuel shall be placed back into the canister and returned to Basin Storage.

NOTE: If dumped fuel cannot be returned to the canister, it will be packaged into a new canister and returned to Basin Storage.

DP-26 7. Record "Yes" or "No" for Stuck Fuel on Phase 3/4 FRS/IWTS Data Sheet.

DP-27 8. Record Scale Tare Weight on Phase 3/4 FRS/IWTS Data Sheet.

DP-28 9. Record Empty Canister Weight on Phase 3/4 FRS/IWTS Data Sheet.

\subsection{Separate and Inspect Fuel}

1. Ensure a minimum of three members of the fuel inspection team are present to evaluate fuel separation.

2. Request OTD to proceed with sorting fuel elements (FTP-OP-PSI-054W).

DP-29 3. Record Fuel Inspection Start Time on Phase 3/4 FRS/IWTS Data Sheet.

4. Start video recording of fuel inspection.

5. Record Inspection Team Fuel Condition assessment of each fuel element/assembly viewed on Phase 3/4 FRS Cleaning Process Data Sheet

6. Request OTD to provide alternate assembly view, if required.

7. Record Inspection Team Cleanliness Assessment of Each Fuel Element viewed on Phase 3/4 FRS Cleaning Process Data Sheet . 
8. Request OTD to provide alternate element and sludge collection tray views, if required.

9. Notify OTD when element inspection is complete.

10. Request OTD to clean sludge collection tray using vacuum wand or sludge pickup adapter if requested by Inspection Team.

11. Perform Steps 5 through 10 for each fuel element/assembly viewed in FTP-OP-PSI-054W.

12. Stop Fuel Inspection Video Tape.

NOTE: Signature verification on Phase 3/4 FRS/IWTS Data Sheet signifies that video of inspections has been recorded.

DP-30

13. Record on Phase 3/4 FRS/IWTS Data Sheet the Inspection End Time.

\subsection{Sort and Load Debris}

1. Request Operations to sort and load debris (FTP-OP-PSI-054W).

DP-31 2. Record Debris Sorting Start Time on Phase 3/4 FRS/IWTS Data Sheet.

DP-32 3. Record Debris Sorting End Time on Phase 3/4 FRS/IWTS Data Sheet.

DP-33 4. Record Photograph of debris.

NOTE: Signature verification on Phase 3/4 FRS/IWTS Data Sheet signifies that Photo of Debris has been recorded.

5. Notify OTD that debris photograph has been recorded.

\subsection{Sort and Load Fuel in Basket}

1. Request OTD to Sort Fuel through Go/No-Go Gauge.

DP-34 2. Record Fuel Sort and Load Start Time on Phase 3/4 FRS/IWTS Data Sheet.

3. Consult with OTD to load fuel into MCO Fuel Basket

4. Request OTD to Load Fuel into MCO Fuel Basket.

DP-35 5. Record Top View Photograph of Fuel loaded into MCO Fuel Basket.

NOTE: Signature verification on Phase 3/4 FRS/IWTS Data Sheet signifies that Fuel Basket Photograph has been recorded. 
DP-36

DP-37

\subsection{Load Fuel in Canister}

1. Request OTD to Load fuel in canister (FTP-OP-PSI-059W).

DP-38 2. Record scale tare weight on Phase 3/4 FRS/IWTS Data Sheet.

DP-39 3. Record Fuel Starting Canister Weight on Phase 3/4 FRS/IWTS Data Sheet.

DP-40 4. Record Fuel Canister Loading Start Time on Phase 3/4 FRS/IWTS Data Sheet.

DP-41 5. Record Fuel Canister Loading End Time on Phase 3/4 FRS/IWTS Data Sheet.

DP-42 6. Record Scale Tare Weight on Phase 3/4 FRS/IWTS Data Sheet.

DP-43 7. Record Loaded Canister Weight on Phase 3/4 FRS/IWTS Data Sheet.

8. Request OTD to transfer loaded fuel canister to Basin Storage location per OP-07-113W.

\subsection{Load Scrap Fuel}

1. Request OTD to load scrap fuel pieces larger than 3-inches in their greatest dimension (FTP-OP-PSI-059W).

DP-44 2. Record Scale Tare Weight on Phase 3/4 FRS/IWTS Data Sheet.

DP-45

3. Record Scrap Fuel Canister Weight on Phase 3/4 FRS/IWTS Data Sheet.

DP-46 4. Record Scrap Fuel Loading Start Time on Phase 3/4 FRS/IWTS Data Sheet.

DP-47 5. Record Scrap Fuel Loading End Time on Phase 3/4 FRS/WTS Data Sheet.

DP-48 6. Record Scale Tare Weight on Phase 3/4 FRS/IWTS Data Sheet.

DP-49 7. Record Scrap Canister Weight on Phase 3/4 FRS/IWTS Data Sheet.

\subsection{Sort and Load Coarse Scrap}

1. Request OTD to sort and load coarse scrap (FTP-OP-PSI-059W). 
DP-50 2. Record Coarse Scrap Sorting Start Time on Phase 3/4 FRS/IWTS Data Sheet.

DP-51 3. Record Coarse Scrap Sorting End Time on Phase 3/4 FRS/IWTS Data Sheet.

DP-52 4. Record first photograph of coarse scrap on grid plate.

NOTE: Signature Verification on Phase 3/4 FRS/IWTS Data Sheet signifies that First Photo of coarse scrap on grid plate has been recorded.

5. Notify OTD that first coarse scrap photograph has been recorded.

DP-53 6. Record second photograph of coarse scrap on grid plate.

NOTE: Signature Verification on Phase 3/4 FRS/IWTS Data Sheet signifies that Second Photo of coarse scrap on grid plate has been recorded.

7. Notify OTD that second coarse scrap photograph has been recorded.

DP-54 8. Record Coarse Scrap Loading Start Time on Phase 3/4 FRS/IWTS Data Sheet.

DP-55 9. Record Coarse Scrap Loading End Time on Phase 3/4 FRS/IWTS Data Sheet.

DP-56 10. Record Scale Tare Weight on Phase 3/4 FRS/IWTS Data Sheet.

DP-57 11. Record Scrap Canister Weight on Phase 3/4 FRS/IWTS Data Sheet.

\subsection{Load Fine Scrap}

1. Request OTD to load fine scrap into canister (FTP-OP-PSI-059W).

DP-58 2. Record Fine Scrap Loading Start Time on Phase 3/4 FRS/IWTS Data Sheet.

DP-59 3. Record first photograph of scrap on grid plate.

NOTE: Signature Verification on Phase 3/4 FRS/IWTS Data Sheet signifies that First Photo of fine scrap on grid plate has been recorded.

4. Notify OTD that first fine scrap photograph has been recorded. 
DP-60 5. Record second photograph of fine scrap on grid plate.

NOTE: Signature Verification on Phase 3/4 FRS/IWTS Data Sheet signifies that Second Photo of fine scrap on grid plate has been recorded.

6. Notify OTD that second fine scrap photograph has been recorded.

DP-61 7. Record Fine Scrap Loading End Time on Phase 3/4 FRS/IWTS Data Sheet.

DP-62 8. Record Scale Tare Weight OTD on Phase 3/4 FRS/IWTS Data Sheet.

DP-63 9. Record Scrap Canister Weight on Phase 3/4 FRS/IWTS Data Sheet.

\subsection{Load Scrap from PCM Wash and Strainer Baskets}

1. Request OTD to load PCM wash and strainer basket scrap into canister per FTP-OP-PSI-059W.

DP-64 2. Record PCM Wash Basket Clean-Out Start Time on Phase 3/4 FRS/IWTS Data Sheet.

DP-65 3. Record PCM Wash Basket Clean-Out End Time on Phase 3/4 FRS/IWTS Data Sheet.

DP-66 4. Record PCM wash basket scrap photograph on grid plate . NOTE: Signature Verification on Phase 3/4 FRS/IWTS Data Sheet signifies that PCM Wash Basket photograph has been recorded.

5. Notify OTD that PCM wash basket scrap photograph has been recorded.

DP-67 6. Record PCM Strainer Removal Start Time on Phase 3/4 FRS/IWTS Data Sheet.

DP-68 7. Record PCM Strainer Removal End Time on Phase 3/4 FRS/IWTS Data Sheet.

DP-69 8. Record Scale Tare Weight on Phase 3/4 FRS/IWTS Data Sheet.

DP-70 9. Record Strainer Weight on Phase 3/4 FRS/IWTS Data Sheet.

DP-71

10. Record PCM Strainer Cleanout Start Time on Phase 3/4 FRS/IWTS Data Sheet.

DP-72 11. Record PCM Strainer Cleanout End Time on Phase 3/4 FRS/IWTS Data Sheet. 
DP-73 12. Record Scale Tare Weight on Phase 3/4 FRS/IWTS Data Sheet.

DP-74

DP-75

13. Record PCM Strainer Weight on Phase 3/4 FRS/IWTS Data Sheet.

DP-76

DP-77

DP-78

DP-79

DP-80

\subsection{Process Scrap Canister}

1. Request OTD to process scrap canister per FTP-OP-PSI-059W.

DP-81 2. Record Scale Tare Weight on Phase 3/4 FRS/IWTS Data Sheet, if applicable.

DP-82 3. Record Scrap Canister Weight on Phase 3/4 FRS/IWTS Data Sheet, if applicable.

DP-83 4. Record Scrap Depth on Phase 3/4 FRS/IWTS Data Sheet.

DP-84 5. Record END TIME on Phase 3/4 FRS/IWTS Data Sheet. 


\subsection{DATA SHEETS}

Examples of the following data sheets are attached.

Attachment A Phase 3/4 FRS/IWTS Data Sheet.

Attachment B FRS Cleaning Process Data Sheet

Attachment $\mathrm{C}$ Test Equipment Calibration Log

Attachment D Installed Equipment Calibration Log

Attachment E End of Shift Test Status Report

Attachment $F \quad$ Pre-Job Safety Briefing Signature Sheet 


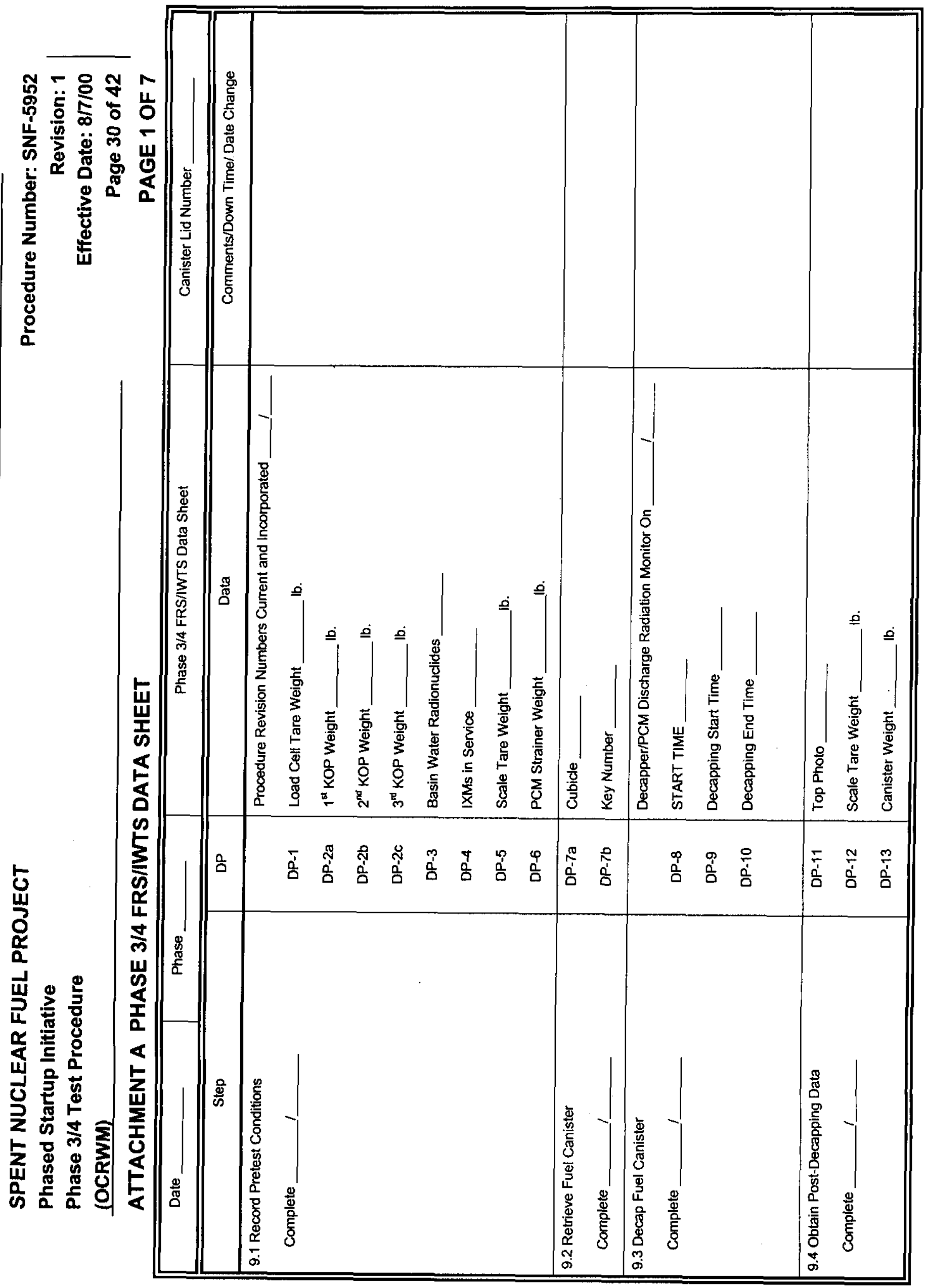




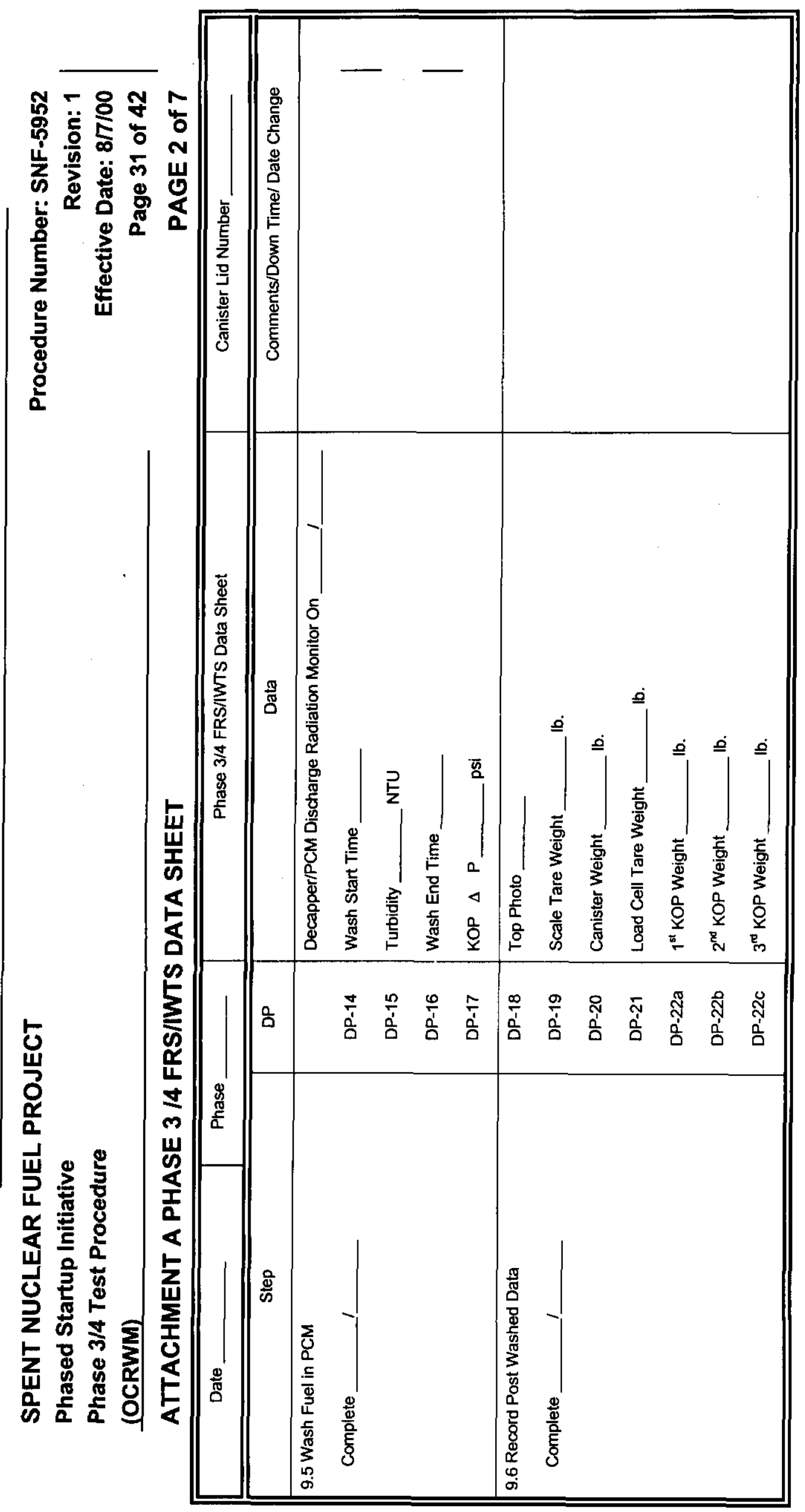




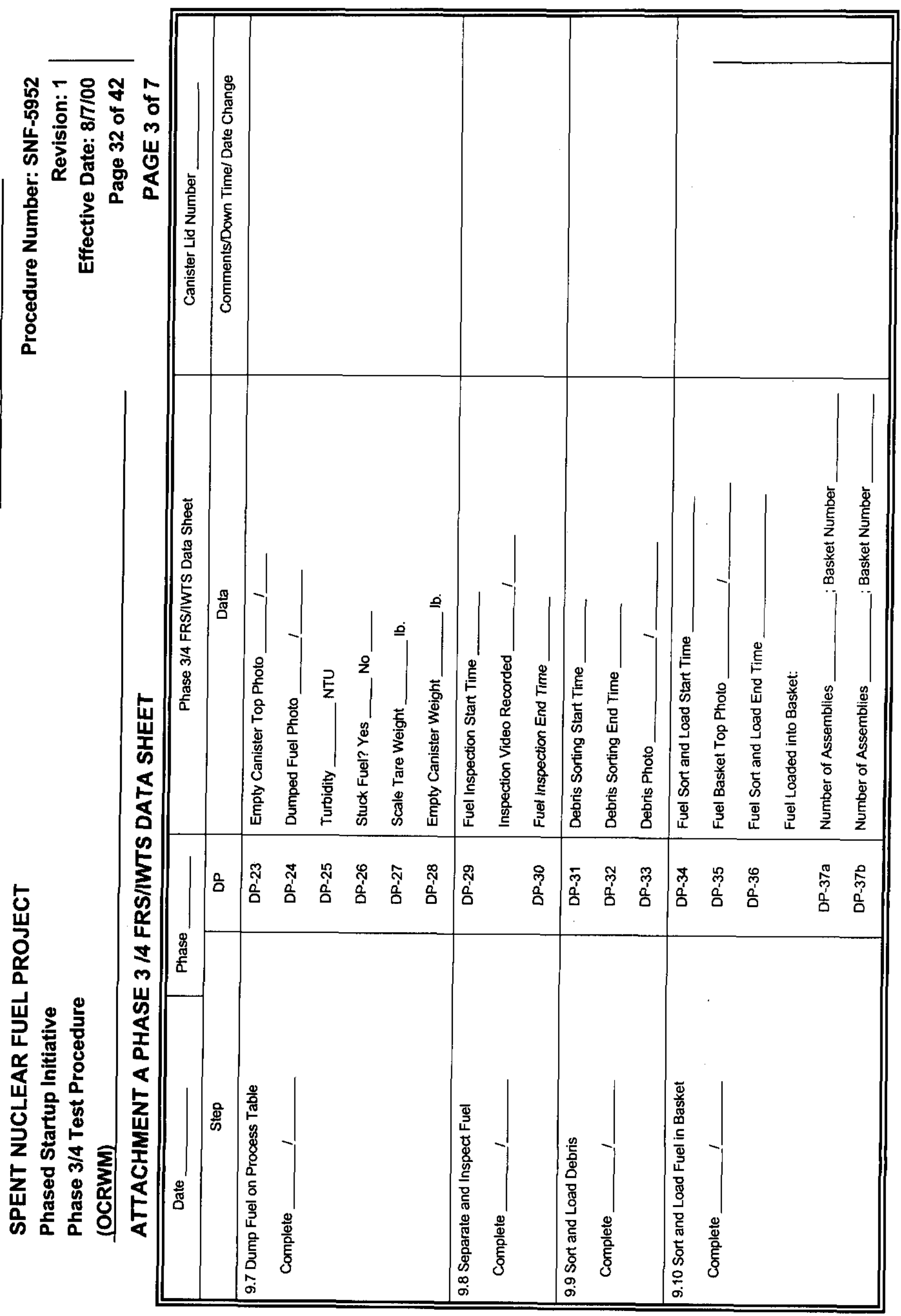




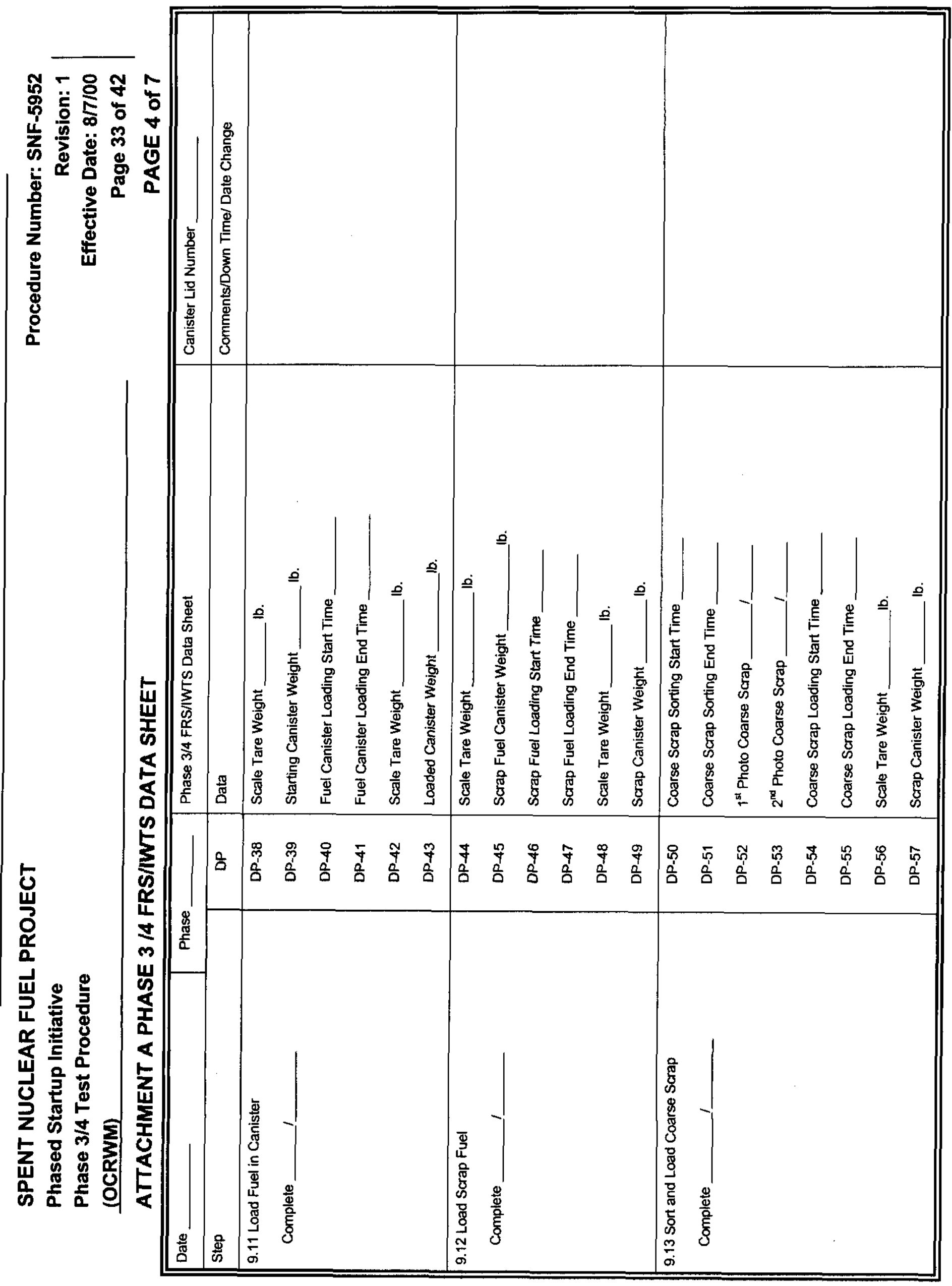




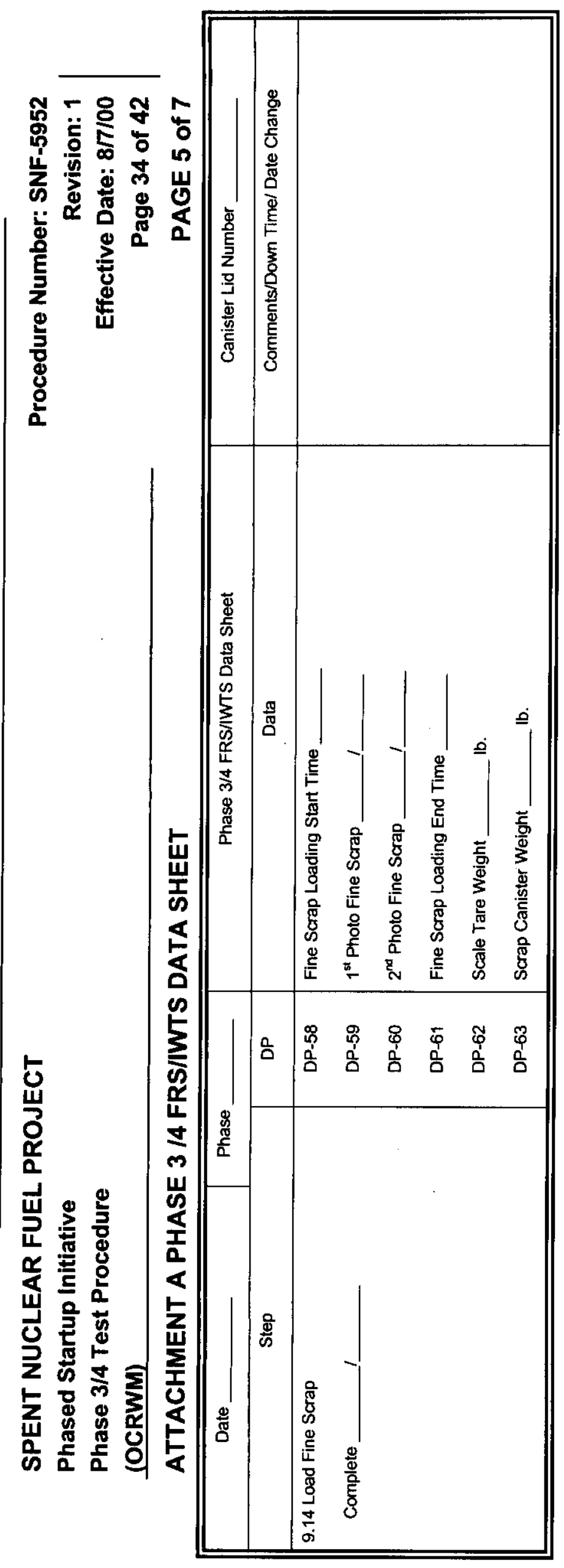




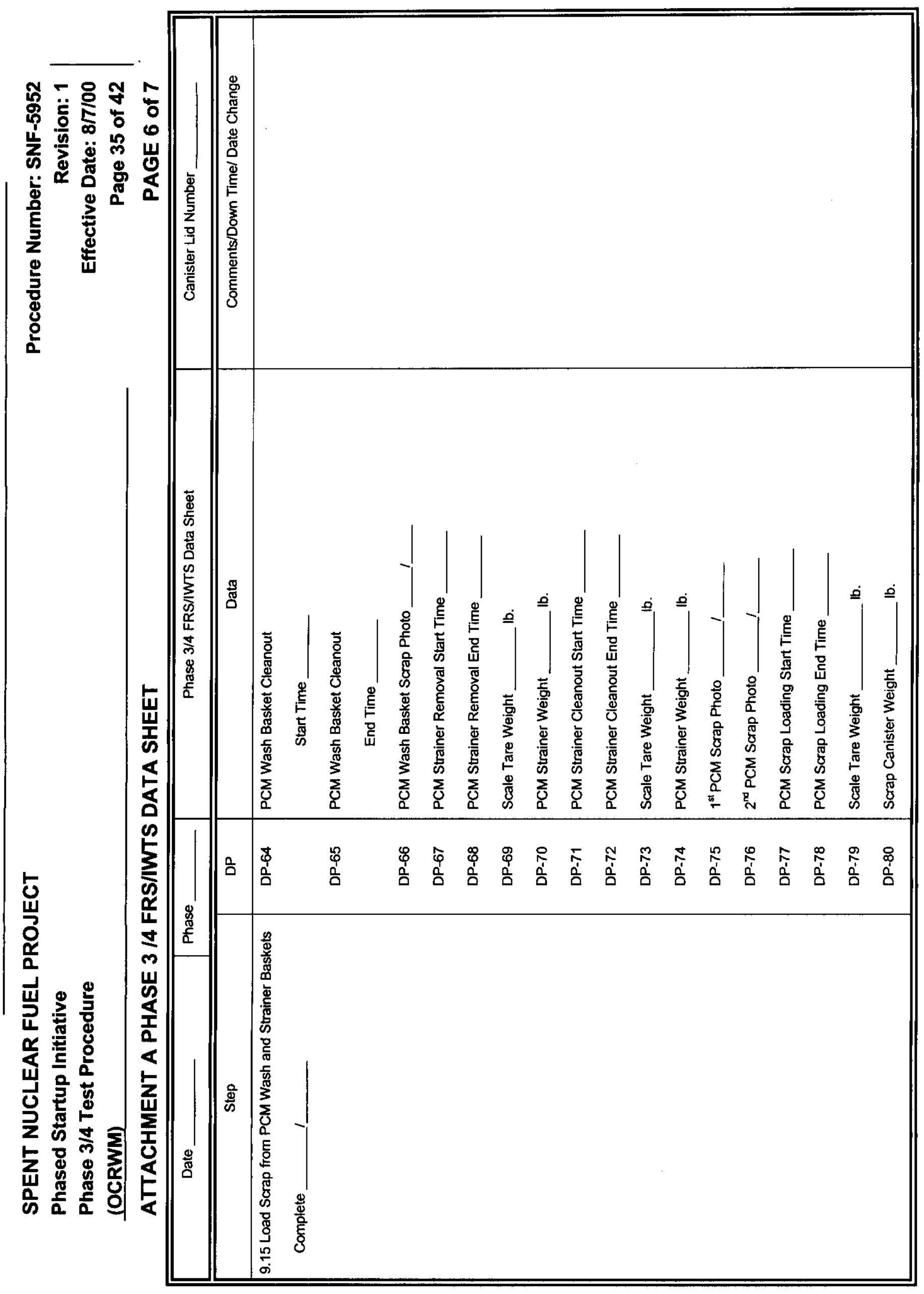




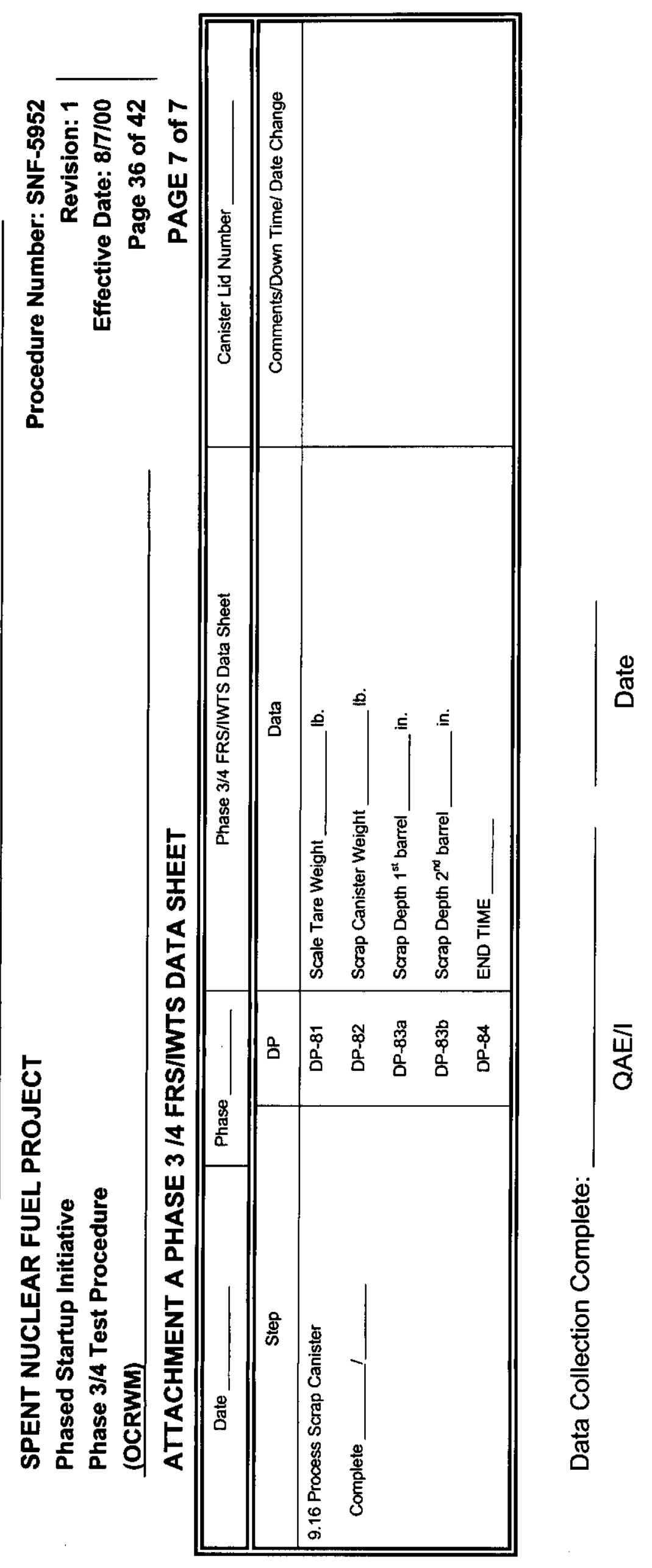


Phase 3/4 Test Procedure

\section{ATTACHMENT B PHASE 3/4 FRS CLEANING PROCESS DATA SHEET (OCRWM)} PAGE 1 OF 2

Date: Time:

CANISTER ID:

\section{CANISTER INFORMATION}

Canister Type: __ Mark I Aluminum, Mark I Stainless Steel, Mark II Stainless Steel

Fuel Type: MKIV, MKIA, SPR, NAT

Key Number

\section{OPERATING PARAMETERS}

Cleaning Cycle Time $=$ minutes

Number of PCM Rotations:

High Pressure Flush Nozzles Flow Rate: gpm

Flush Nozzles Pressure: psig

Discharge Flow Rate ( $75 \mathrm{gpm}$ or greater):

\begin{tabular}{|c|c|c|c|c|c|c|c|c|}
\hline \multirow{2}{*}{ Assembly } & \multirow{2}{*}{ Inner/Outer } & \multicolumn{4}{|c|}{ Fuel Condition } & \multicolumn{2}{|c|}{ Inspection Results } & \multirow{2}{*}{ Comments } \\
\hline & & Intact & Breached & Defective & Bad & Clean & Not Clean & \\
\hline \multirow[b]{2}{*}{1} & Inner & & & & & & & \\
\hline & Outer & & & & & & & \\
\hline \multirow[b]{2}{*}{2} & Inner & & & & & & & \\
\hline & Outer & & & & & & & \\
\hline \multirow[b]{2}{*}{3} & Inner & & & & & & & \\
\hline & Outer & & & & & & & \\
\hline \multirow[b]{2}{*}{4} & inner & & & & & & & \\
\hline & Outer & & & & & & & \\
\hline \multirow[b]{2}{*}{5} & Inner & & & & & & & \\
\hline & Outer & & & & & & & \\
\hline \multirow[b]{2}{*}{6} & Inner & & & & & & & \\
\hline & Outer & & & & & & & \\
\hline \multirow[b]{2}{*}{7} & Inner & & & & & & & \\
\hline & Outer & & & & & & & \\
\hline \multirow[b]{2}{*}{8} & Inner & & & & & & & \\
\hline & Outer & & & & & & & \\
\hline \multirow[b]{2}{*}{9} & Inner & & & & & & & \\
\hline & Outer & & & & & & & \\
\hline \multirow[b]{2}{*}{10} & Inner & & & & & & & \\
\hline & Outer & & & & & & & \\
\hline \multirow[b]{2}{*}{11} & Inner & & & & & & & \\
\hline & Outer & & & & & & & \\
\hline \multirow[b]{2}{*}{12} & Inner & & & & & & & \\
\hline & Outer & & & & & & & \\
\hline \multirow[b]{2}{*}{13} & Inner & & & & & & & \\
\hline & Outer & & & & & & & \\
\hline \multirow[b]{2}{*}{14} & Inner & & & & & & & \\
\hline & Outer & & & & & & & \\
\hline \multicolumn{6}{|c|}{ Total } & & & \\
\hline
\end{tabular}


SPENT NUCLEAR FUEL PROJECT

Phased Startup Initiative

Phase 3/4 Test Procedure

(OCRWM)

Procedure Number: SNF-5952

Revision: 1

Effective Date: $8 / 7 / 00$

Page 38 of 42

Canister No.

Attachment B Phase 3/4 FRS Cleaning Process Data Sheet (OCRWM) Page 2 of 2

Comments:

Fuel Inspection Team Members Signatures

Print Name

Signature

Date 
SPENT NUCLEAR FUEL PROJECT

Procedure Number: SNF-5952

Phased Startup Initiative

Revision: 1

Phase 3/4 Test Procedure

Effective Date: $8 / 7 / 00$

(OCRWM)

Page 39 of 42

ATTACHMENT C TEST EQUIPMENT CALIBRATION LOG

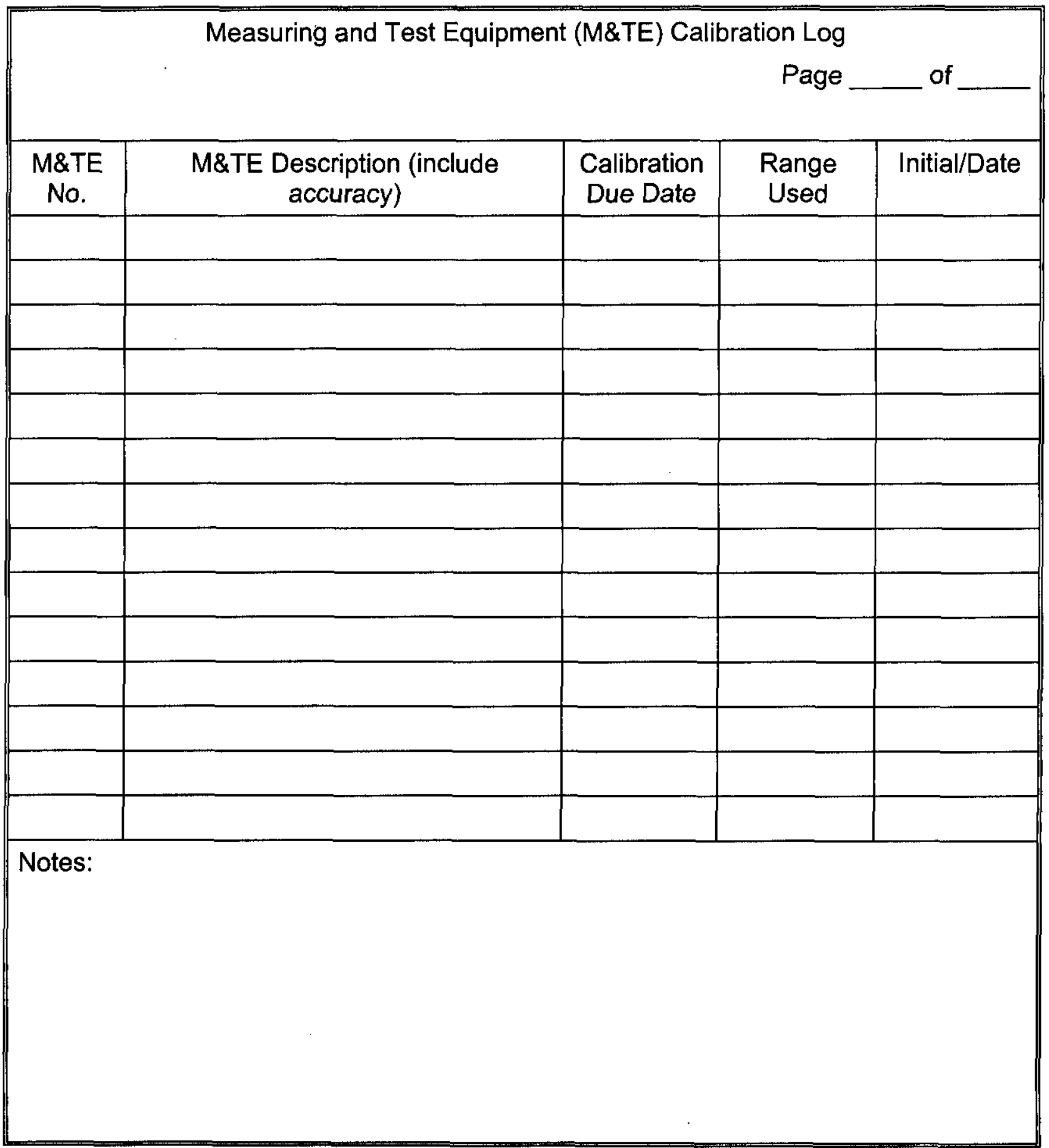




\section{SPENT NUCLEAR FUEL PROJECT}

Procedure Number: SNF-5952

Phased Startup Initiative

Revision: 1

Phase 3/4 Test Procedure

Effective Date: 8/7/00

(OCRWM)

Page 40 of 42

ATTACHMENT D INSTALLED EQUIPMENT CALIBRATION LOG

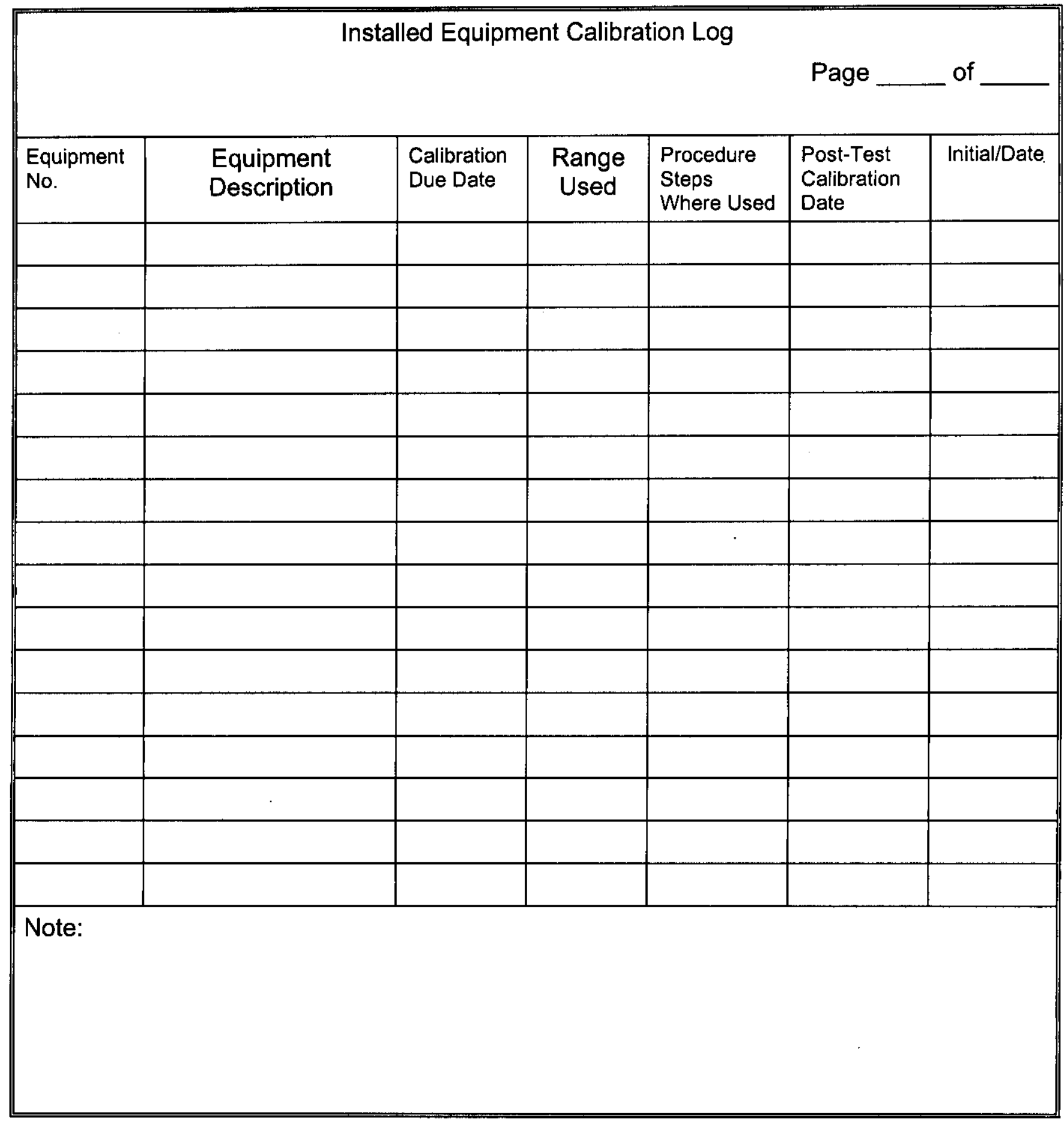


SPENT NUCLEAR FUEL PROJECT

Procedure Number: SNF-5952

Phased Startup Initiative

Revision: 1

Phase 3/4 Test Procedure Effective Date: 8/7/00

(OCRWM) Page 41 of 42

ATTACHMENT E END-OF SHIFT TEST STATUS REPORT, PSI PHASE $3 / 4$

Page 1 of 1

Date/Time:

Canister In-Process: (original lid \# or N/A)

End of Shift Procedure Status

SNF-5952 Test Procedure Step

Completed through end of shift:

Referenced FTP Step completed

Through end of shift:

FTP \#:

Step \#:

Comments:

Expected Test Restart Description

Continue with SNF-5952 Test Procedure Step:

By performing (if required)

FTP \#:

Step \#:

Comments (clarify planned next procedure step after daily prestart completed):

Prepared by:

Name/Signature/Date 
SPENT NUCLEAR FUEL PROJECT

Phased Startup Inltiatlve

Phase 3/4 Test Procedure

(OCRWM)

\section{ATTACHMENT F PRE-JOB SAFETY BRIEFING SIGNATURE SHEET}

\section{Page 1 of 1}

\begin{tabular}{|c|c|c|c|}
\hline \multicolumn{4}{|c|}{ SPENT NUCLEAR FUEL PROJECT } \\
\hline NAME (PRINTED) & SIGNATURE & INITIALS & DATE \\
\hline & & & \\
\hline & & & \\
\hline & & & \\
\hline & & & \\
\hline & & & \\
\hline & & & \\
\hline & & & \\
\hline & & & \\
\hline & & & \\
\hline & & & \\
\hline & & & \\
\hline & 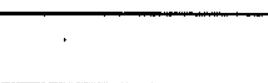 & & \\
\hline & & & \\
\hline & & & \\
\hline & & & \\
\hline & & & \\
\hline & & & \\
\hline & & & \\
\hline & & & \\
\hline & & & \\
\hline
\end{tabular}

Revision: 1

Effective Date: $8 / 7 / 00$

Page 42 of 42 


\section{DISTRIBUTION SHEET}

\begin{tabular}{|c|c|c|c|c|c|}
\hline \multirow{2}{*}{$\begin{array}{l}\text { To } \\
\text { Distribution }\end{array}$} & \multirow{2}{*}{\multicolumn{3}{|c|}{$\begin{array}{l}\text { From } \\
\text { Process Engineering }\end{array}$}} & \multicolumn{2}{|l|}{ Page 1 of 1} \\
\hline & & & & \multicolumn{2}{|l|}{ Date $7 / 20 / 00$} \\
\hline \multirow{2}{*}{\multicolumn{4}{|c|}{$\begin{array}{l}\text { Project Title/Work Order } \\
\text { Phased Startup Initiative Phase 3/4 Test Procedure (OCRWM) }\end{array}$}} & \multicolumn{2}{|l|}{ EDT No. N/A } \\
\hline & & & & \multicolumn{2}{|c|}{ ECN No. 661460} \\
\hline Name & MSIN & $\begin{array}{c}\text { Text } \\
\text { With All } \\
\text { Attach. }\end{array}$ & Text Only & $\begin{array}{l}\text { Attach./ } \\
\text { Appendix } \\
\text { Only }\end{array}$ & $\begin{array}{l}\text { EDT/ECN } \\
\text { Only }\end{array}$ \\
\hline
\end{tabular}

Spent Nuclear Fuel Project

R. D. Crowe

P. E. Davis

W. A. Decker

J. A. Dent

J. R. Frederickson

S. D. Godfrey

J. C. Gruber

D. F. Hicks

V. L. Hoefer

J. A. Kimbrough

S. B. Klekar

J. J. Klos

B. J. Knutson

J. M. Kurta

M. J. Langevin

C. D. Lucas

J. D. Mathews

C. T. Miller

W. C. Miller

J. W. Neskas

A. L. Pajunen (5)

A. L. Pitner

L. S. Semmens

R. A. Sexton

J. L. Shelor

J. P. Sloughter

D. W. Smith

P. E. Stanley

G. E. Stegen

J. A. Swenson

J. A. Thomason

J. E. Truax

D. J. Watson

J. H. Wicks

SNF Project

SNF Training

SNF Procedures
R3-26

$\mathrm{X} 3-80$

$\mathrm{X} 3-68$

$\mathrm{X} 3-65$

R3-86

$\mathrm{X} 3-88$

$\mathrm{X} 3-86$

S7-12

R3-86

$\mathrm{X} 3-65$

$\mathrm{X} 3-65$

$\mathrm{X} 4-02$

B6-01

X4-01

$\mathrm{X} 4-01$

X3-74

X3-65

X3-79

R3-11

R3-86

R3-86

X3-79

R3-86

X4-04

K9-46

S2-48

$\mathrm{X} 4-01$

X4-01

R3-11

X3-78

X3-71

X3-79

X3-71

R3-11

S2-45

X3-86
R3-86

$\mathrm{X}$

$\mathrm{X}$

$\mathrm{X}$

$\mathrm{X}$

$\mathrm{X}$

$\mathrm{X}$

$\mathrm{X}$

$\mathrm{X}$

$\mathrm{X}$

$\mathrm{X}$

$\mathrm{X}$

$\mathrm{X}$

$\mathrm{X}$

$\mathrm{X}$

$\mathrm{X}$

$\mathrm{X}$

$\mathrm{X}$

$\mathrm{X}$

$\mathrm{X}$

$\mathrm{X}$

$\mathrm{X}$

$\mathrm{X}$

$\mathrm{X}$

$\mathrm{X}$

$\mathrm{X}$

$\mathrm{X}$

$\mathrm{X}$

$\mathrm{X}$

$\mathrm{X}$

$\mathrm{X}$

$\mathrm{X}$

$\mathrm{X}$

$\mathrm{X}$

$\mathrm{X}$

$\mathrm{X}$

$\mathrm{X}$

$\mathrm{X}$

R3-81 X

R3-81 X

$\mathrm{X}$

U.S. Department of Energy - Richland Operations Office

R. M. Hiegel

P. G. Loscoe 